\title{
Modeling the meteorological and chemical effects of secondary organic aerosols during an EUCAARI campaign
}

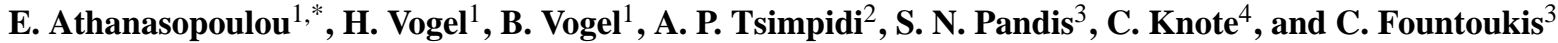 \\ ${ }^{1}$ Institute for Meteorology and Climate Research, Karlsruhe Institute of Technology, Karlsruhe, Germany \\ ${ }^{2}$ School of Civil and Environmental Engineering, Georgia Institute of Technology, Atlanta, GA, 30332, USA \\ ${ }^{3}$ Institute of Chemical Engineering Sciences, Foundation for Research and Technology Hellas (FORTH), Patras, Greece \\ ${ }^{4}$ Laboratory for Air Pollution/Env. Technology, Empa Materials and Science, 8600 Duebendorf, Switzerland \\ * now at: National and Kapodistrian University of Athens, Faculty of Physics, Dept. of Environmental Physics and \\ Meteorology, Athens, Greece
}

Correspondence to: E. Athanasopoulou (eathana@phys.uoa.gr), B. Vogel (bernhard.vogel@kit.edu)

Received: 26 July 2012 - Published in Atmos. Chem. Phys. Discuss.: 23 August 2012

Revised: 14 December 2012 - Accepted: 28 December 2012 - Published: 17 January 2013

\begin{abstract}
A volatility basis set (VBS) approach for the simulation of secondary organic aerosol (SOA) formation is incorporated in the online coupled atmospheric model system COSMO-ART and applied over Europe during the EUCAARI May 2008 campaign. Organic aerosol performance is improved when compared to the default SOA module of COSMO-ART (SORGAM) against high temporal resolution aerosol mass spectrometer ground measurements. The impact of SOA on the overall radiative budget was investigated. The mean direct surface radiative cooling averaged over Europe is $-1.2 \mathrm{~W} \mathrm{~m}^{-2}$, representing approximately $20 \%$ of the total effect of aerosols on the radiative budget. However, responses are not spatially correlated with the radiative forcing, due to the nonlinear interactions among changes in particle chemical composition, water content, size distribution and cloud cover. These interactions initiated by the effect of SOA on radiation are found to result even in a positive forcing in specific areas. Further model experiments showed that the availability of nitrogen oxides slightly affects SOA production, but that the aging rate constant used in the VBS approximation and boundary concentrations assumed in the model should be carefully selected. The aging of SOA is found to reduce hourly nitrate levels by up to $30 \%$, while the condensation of inorganic species upon pre-existing, SOA-rich particles results in a monthly average increase of $5 \%$ in sulfate and ammonium formation in the accumulation mode.
\end{abstract}

\section{Introduction}

Organic aerosol (OA) is a significant, if not the most important, component of submicron particles $\left(\mathrm{PM}_{1}\right)$ on the global scale (Zhang et al., 2007). Organic matter can exist in the particle phase from the moment it is emitted as primary organic aerosol (POA) and as secondary organic aerosol (SOA) arising from oxidation of volatile, intermediate volatility and semi-volatile organic compounds in the atmosphere (Robinson et al., 2007). OA measurements are able to distinguish hydrocarbon-like (HOA) from oxidized organic aerosol (OOA), and it has been found that there is a strong correlation between HOA and POA, and between OOA and SOA. Jimenez et al. (2009) argue that atmospheric OOA evolves through a dynamic aging process and continually repartitions between the particle and gas phases (chemical aging), leading to a more oxidized, less volatile and more hygroscopic aerosol. The deconvolution of OA measurements into HOA and OOA components has shown the predominance of the latter, accounting for more than 80 and $95 \%$ of the total OA in urban downwind, and remote sites, respectively (Zhang et al., 2007; Morgan et al., 2012b).

Recent studies have shown that OA concentrations are often underestimated, when semi-volatile compounds are not included in global and regional chemical transport models (Volkamer et al., 2006; Dzepina et al., 2009; O'Donnell et al., 2011). An efficient way to describe the chemical evolution of the numerous semi-volatile organic compounds in 
models is to treat them as lumped species that span a range of effective saturation concentrations (Donahue et al., 2006). Recent model applications using different volatility basis set (VBS) approaches confirm their ability to provide improved predictions of OA concentration (Murphy and Pandis., 2009; Tsimpidi et al., 2010, 2011; Shrivastava et al., 2011; Farina et al., 2010; Murphy et al., 2011; Fountoukis et al., 2011; Bergström et al., 2012).

Oxidised organic aerosol has significant implications for the radiative budget in a wide range of continental environments (Kanakidou et al., 2005; Tsigaridis et al., 2005; Chen et al., 2009). When mixed with inorganic components and soot, OOA increases aerosol scattering and contributes to its negative direct radiative forcing (Ming et al., 2005; Forster et al., 2007; Myhre et al., 2009; O’Donnell et al., 2011). Increases in aerosol extinction related to the presence of organic matter are mostly driven by large amounts of associated water, and enhanced mass due to condensation (Morgan et al., 2010a). Furthermore, there is an indirect impact of condensing organic compounds on radiative forcing due to the efficient growth of freshly nucleated particles into cloud condensation nuclei $(\mathrm{CCN})$ in pristine areas and $\mathrm{CCN}$ decreases in polluted areas (Pierce et al., 2012; O'Donnell et al., 2011).

In cloudy conditions, the direct radiative effects of aerosol are accompanied by semi-direct effects (Vogel et al., 2009). For example, dust aerosols absorb solar and infrared radiation, heat and change the stability of the atmosphere, and thereby influence cloud formation, and hence affect aerosol radiative forcing (Han et al., 2012). The nonlinearity involved in the feedbacks among such processes is a source of uncertainty for the magnitude of the impact of OA on climate (Johnson et al., 2004; Penner et al., 2003). In clear-sky conditions, particles are exposed to incoming radiation and their cooling effect is intensified. To the contrary, radiative forcing in a standard (total-sky) situation is weakened by extinction over areas covered by clouds (Ming et al., 2005; Han et al., 2012). In this case, cloud optical depth is higher than the aerosol optical depth, dominating radiation changes and is responsible for the absence of correlation between aerosol concentration and radiation fields (Vogel et al., 2009).

The observed difficulty in accurately modeling semivolatile organic compounds is a significant limitation in attempts to constrain the direct radiative forcing by aerosols. This is due to limited understanding of the principal SOA formation pathways, the relative contribution of biogenic and anthropogenic VOCs, and the magnitude of their emissions (Carslaw et al., 2010). The uncertainty in the impact of aerosols on radiative forcing arising from this lack of knowledge is greatest in areas where OA is a major component of the aerosol burden and during major pollution episodes (Morgan et al., 2010a).

In this study, organic aerosol is simulated with the regional atmospheric model COSMO-ART (Vogel et al., 2009). Descriptions of gas-phase chemistry and aerosol processes have been modified to include a condensed VBS scheme in an attempt to improve the ability of COSMO-ART to reproduce OA observations. The European Aerosol Cloud Climate and Air Quality Interactions (EUCAARI) measurements of OA during May 2008 are used to evaluate this updated model. Unlike all previous modelling studies over Europe (e.g. Andersson-Skold and Simpson, 2001; Simpson et al., 2007; Bessagnet et al., 2008; Fountoukis et al., 2011; Bergström et al., 2012), the interactive coupling of meteorology and chemistry present in COSMO-ART, allows for an assessment of the direct radiative forcing of OA as predicted by the VBS scheme. In parallel, simulations of selected scenarios are used to test the response of OA predictions to various parameters in this VBS scheme. Inter-comparisons of COSMO-ART predictions with a conventional SOA scheme and with a VBS-including air quality model are used to evaluate the performance of different modelling approaches. Additional model experiments are performed to estimate the relative contribution of biogenic and anthropogenic sources on the formation of organic matter in the atmosphere and to examine whether or not the chemical aging of SOA affects secondary inorganic aerosol formation.

\section{Model description}

\subsection{COSMO-ART}

This study uses the regional atmospheric model COSMOART (Vogel et al., 2009) (ART stands for Aerosols and Reactive Trace gases), in which atmospheric chemistry is onlinecoupled to the COSMO regional numerical weather prediction and climate model (Baldauf et al., 2011). The online coupling is realized in a consistent way using the same spatial and temporal resolution for all scalars (temperature, radiative fluxes, gas and aerosol concentrations, etc). For processes affecting all scalars, as for example advection, the same numerical schemes are applied. Detailed model description can be found in the aforementioned publications as well as in Stanelle et al. (2010), Bangert et al. (2012) and Knote et al. (2011).

The gaseous chemistry in COSMO-ART is simulated by a modified version of the Regional Acid Deposition Model, Version 2 (RADM2) mechanism (Stockwell et al., 1990), which is extended to describe secondary organic aerosol formation (Schell et al., 2001) and hydroxyl radical recycling due to isoprene chemistry (Geiger et al, 2003). Aerosol dynamics are simulated with the modal aerosol module MADE (Ackermann et al., 1998), improved by explicit treatment of soot aging through condensation of inorganic (Riemer et al., 2003) and organic substances. The five modes that represent the aerosol population contain: pure soot, secondary mixtures of sulfates, nitrates, ammonium, organics and water (nucleation and accumulation mode), and the internal mixtures of all these species in both modes. Aerosol species are 
transferred among these mixtures through condensation and coagulation. A separate coarse mode contains additional primary emitted particles. Meteorologically-affected emissions are also online-coupled to the model system. Sea-salt and desert dust emission algorithms are described in Vogel et al. (2006, 2009). The biogenic VOC emissions are calculated as functions of the land use type based on the Global Land Cover 2000 dataset (Bartholome and Belward, 2005) and the modeled temperatures and radiative fluxes (Vogel et al., 1995). Sedimentation, advection, washout and turbulent diffusion also modify the aerosol distributions.

The partitioning of the inorganic aerosol components between the gas and particulate phases is simulated by the ISORROPIA II module (Fountoukis and Nenes, 2007). Since organic aerosol is the main focus of this study, the description of the SOA chemistry and of the organic mass transfer between phases, is separately described in the next section.

COSMO-ART is fully online-coupled, and allows for feedbacks of aerosols on temperature, radiation and CCN. Analytical description of the modules incorporated for this purpose exists in Vogel et al. (2009) and Bangert et al. (2011). The radiation scheme used within the model to calculate the vertical profiles of the short- and longwave radiative fluxes is GRAALS (Ritter and Geleyn, 1992). Aerosol forcing on the radiative budget involves several nonlinear feedback mechanisms. Radiative fluxes are modified by the aerosol water content mass and particle size distributions. This results in changes in the atmospheric temperature, and subsequently in humidity, cloud distributions, precipitation, wash out and aerosol mass concentrations. The chemical composition and mass of particles are also affected by the photolysis rates, which are a function of radiative fluxes.

The spectral range covered by GRAALS is 0.25 to $104.5 \mu \mathrm{m}$, divided in eight bands. The calculation of radiative fluxes depends on three aerosol optical properties: extinction coefficients, single scattering albedo and asymmetry parameters for each of the five modes mentioned above, in each of the eight bands. These data have been calculated by applying the Mie theory through the code by Bohren and Huffman (1983). The input data used are the initial modal geometric mean diameters and the complex refractive indices of each chemical constituent in each mode. The initialization and calculation of the size distribution of each mode, as well as refractive indices for ammonium sulfate, nitrate and water are given in Riemer et al. (2003). Refractive indices for soot and organics are provided in Baeumer et al. (2007). Specifically for organics, the complex refractive index varies from $1.54+0.03 i$ at a wavelength of $250 \mathrm{~nm}$, to $1.50+1.1 \times 10^{-5} i$ (at $1.4 \mu \mathrm{m}$ ) and to $1.50+0.02 i($ at $4 \mu \mathrm{m})$. These data are similar to calculated values for SOA coated on soot particles (Schnaiter et al., 2005). In the long wave range, the refractive index is set to $2.0+0.1 i$. The Mie code was applied offline because of the computational cost for calculations at each grid point and time step. The parameters derived from this procedure and used by GRAALS are given in Vogel et al. (2009).

\subsection{Secondary organic aerosol modules}

In the version of COSMO-ART applied for the current study, there is the option of choosing between two different SOA modules: The SORGAM which is the default SOA module of COSMO-ART, analytically described in Schell et al. (2001) and used in several applications (Grell et al., 2005; Stern et al., 2008; Elleman and Covert, 2009; Zhao et al., 2012; Chuang et al., 2011; Herwehe et al., 2011) and the VBS, which is the newly added SOA module in COSMO-ART, based on the framework proposed by Donahue et al. (2006) and employed in other models (Robinson et al., 2007; Lane et al., 2008; Murphy and Pandis, 2009; Tsimpidi et al., 2010, 2011; Shrivastava et al., 2011).

The SORGAM module incorporates eight SOA precursors: higher alkanes, terminal and internal alkenes, toluene, xylenes, cresol, a-pinene and limonene. These species are oxidized by the hydroxyl radical $(\mathrm{OH})$, ozone $\left(\mathrm{O}_{3}\right)$ and nitrate radical $\left(\mathrm{NO}_{3}\right)$ through seventeen reactions, forming eight condensable products (four of anthropogenic and four of biogenic origin), which then partition between the gas and aerosol phases until thermodynamic equilibrium is reached. The molecular weights of the condensable species range between 150 and $200 \mathrm{~g} \mathrm{~mol}^{-1}$ and their vaporization enthalpy is assumed to be $\Delta H_{\mathrm{vap}}=156 \mathrm{~kJ} \mathrm{~mol}^{-1}$. The equilibrium concentration of each compound in the gas phase depends on its mole fraction in the organic particulate phase and on its saturation vapor pressure. Each added SOA species can exist in the nucleation and accumulation pure and mixed aerosol modes, thus the total number of the SOA species in COSMO-ART when coupled with SORGAM is 32. Further reactions of SOA species (chemical aging) are not treated by SORGAM.

The VBS approach applied in COSMO-ART uses the same precursors as SORGAM, plus isoprene due to recent findings on its role regarding SOA formation (Liao et al., 2007; Karl et al., 2009; Robinson et al., 2011). The semi-volatile products of the oxidation reactions of these VOCs are grouped by their effective saturation concentration $\left(C^{*}\right)$ into four aerosol species with the $C^{*}$ of 1,10 , 100 and $1000 \mu^{-3} \mathrm{~m}^{-3}$ (at $298 \mathrm{~K}$ ) with a molecular weight of $180 \mathrm{~g} \mathrm{~mol}^{-1}$ (Table 1). The aerosol yields used for the production of the four SOA species were measured during recent smog chamber experiments and are also given in the Table 1. This four-product set was suggested by Lane et al. (2008) as satisfactory for the representation of biogenic and anthropogenic organic matter for urban and regional pollution modeling. However, the number of volatility bins and reactions used by different VBS implementations may vary from two (Shrivastava et al., 2011) to nine (Robinson et al., 2007) depending on the desired chemical resolution. A limitation of the one-dimensional VBS approach is that species with 
Table 1. Organic aerosol chemistry treated by the VBS version incorporated in the COSMO-ART model. The rates of the oxidation reactions of SOA precursors are calculated from the Arrhenius equation. SOA1, SOA10, SOA100 and SOA1000 are the four SOA species treated by VBS. The respective SOA yields are the values of a1, a10, a100 and a1000 $\left(\mu \mathrm{g} \mathrm{m}^{-3} / \mu \mathrm{g} \mathrm{m}^{-3}\right)$, measured during recent smog chamber experiments.

\begin{tabular}{|c|c|c|c|c|c|c|}
\hline \multirow[t]{2}{*}{ SOA Precursors } & \multirow[t]{2}{*}{ Description } & \multirow{2}{*}{$\begin{array}{l}\text { Oxidation reactions towards SOA } 1^{*} \text {, SOA } 10^{*} \text {, SOA } 100^{*} \text {, } \\
\text { SOA1000* }\end{array}$} & \multicolumn{4}{|c|}{ SOA yields $\left(\mu \mathrm{g} \mathrm{m}^{-3} / \mu \mathrm{g} \mathrm{m}^{-3}\right)$} \\
\hline & & & a1 & a10 & a100 & a1000 \\
\hline \multicolumn{7}{|l|}{ Anthropogenic } \\
\hline $\mathrm{HC} 8$ & Higher Alkanes & $\mathrm{HC} 8+\mathrm{HO} \rightarrow \mathrm{a} 10 \cdot \mathrm{SOA} 10+0.75 \mathrm{XO}_{2}+\mathrm{H}_{2} \mathrm{O}$ & - & 0.3 & - & - \\
\hline OLT & Terminal Alkenes & 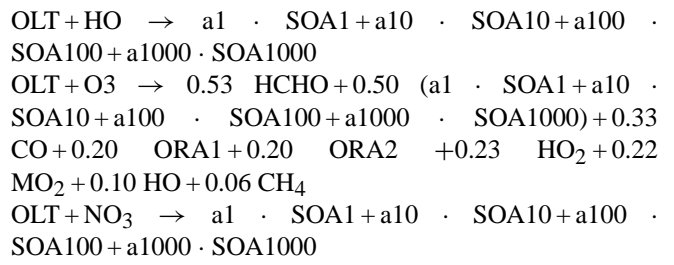 & 0.0045 & 0.009 & 0.06 & 0.225 \\
\hline OLI & Internal Alkenes & $\begin{array}{l}\mathrm{OLI}+\mathrm{HO} \rightarrow a 1 \cdot \mathrm{SOA} 1+\mathrm{a} 10 \cdot \mathrm{SOA} 10+\mathrm{a} 100 \\
\mathrm{SOA} 100+\mathrm{a} 1000 \cdot \mathrm{SOA} 1000 \\
\mathrm{OLI}+\mathrm{O} 3 \rightarrow 0.18 \quad \mathrm{HCHO}+0.72 \quad(\mathrm{a} 1 \cdot \mathrm{SOA} 1+\mathrm{a} 10 \\
\mathrm{SOA} 10+\mathrm{a} 100 \cdot \mathrm{SOA} 100+\mathrm{a} 1000 \cdot \mathrm{SOA} 1000)+0.10 \\
(\mathrm{a} 1 \cdot \mathrm{SOA} 1+\mathrm{a} 10 \cdot \mathrm{SOA} 10+\mathrm{a} 100 \cdot \mathrm{SOA} 100+\mathrm{a} 1000 \cdot \\
\mathrm{SOA} 1000)+0.23 \mathrm{CO}+0.06 \quad \mathrm{ORA} 1+0.29 \mathrm{ORA} 2+0.09 \\
\mathrm{CH} 4+0.26 \mathrm{HO}_{2}+0.14 \mathrm{HO}+0.31 \mathrm{MO}_{2} \\
\mathrm{OLI}+\mathrm{MO}_{3} \rightarrow \text { a } \cdot \quad \mathrm{SOA} 1+\mathrm{a} 10 \cdot \mathrm{SOA} 10+\mathrm{a} 100 \\
\mathrm{SOA} 100+\mathrm{a} 1000 \cdot \mathrm{SOA} 1000\end{array}$ & 0.0225 & 0.0435 & 0.129 & 0.375 \\
\hline TOL & Toluene & $\begin{array}{l}\mathrm{TOL}+\mathrm{HO} \rightarrow 0.75(\mathrm{a} 1 \cdot \mathrm{SOA} 1+\mathrm{a} 10 \cdot \mathrm{SOA} 10+\mathrm{a} 100 \\
\mathrm{SOA} 100+\mathrm{a} 1000 \cdot \mathrm{SOA} 1000)+0.25 \mathrm{CSL}+0.25 \mathrm{HO}_{2}\end{array}$ & 0.01065 & 0.2571 & 0.75 & 0.96435 \\
\hline XYL & Xylene & $\begin{array}{l}\mathrm{XYL}+\mathrm{HO} \rightarrow 0.83(\mathrm{a} 1 \cdot \mathrm{SOA} 1+\mathrm{a} 10 \cdot \mathrm{SOA} 10+\mathrm{a} 100 \\
\mathrm{SOA} 100+\mathrm{a} 1000 \cdot \mathrm{SOA} 1000)+0.17 \mathrm{CSL}+0.17 \mathrm{HO}_{2}\end{array}$ & 0.075 & 0.3 & 0.375 & 0.525 \\
\hline CSL & Cresol & $\begin{array}{l}\mathrm{CSL}+\mathrm{HO} \rightarrow 0.1 \mathrm{HO}_{2}+0.9 \mathrm{XO}_{2}+0.9 \mathrm{TCO} 3-0.9 \mathrm{HO} \\
\mathrm{CSL}+\mathrm{MO}_{3} \rightarrow \mathrm{HMO}_{3}+\mathrm{XNO}_{2}+0.5(\mathrm{a} 1 \cdot \mathrm{SOA} 1+\mathrm{a} 10 \\
\mathrm{SOA} 10+\mathrm{a} 100 \cdot \mathrm{SOA} 100+\mathrm{a} 1000 \cdot \mathrm{SOA} 1000)\end{array}$ & - & - & - & - \\
\hline \multicolumn{7}{|l|}{ Biogenic } \\
\hline ISO $^{* *}$ & Isoprene & $\begin{array}{l}\mathrm{ISO}+\mathrm{HO} \rightarrow \text { a } 1 \cdot \mathrm{SOA}_{1+\mathrm{a} 10} \cdot \mathrm{SOA} 10+\mathrm{a} 100 \\
\mathrm{SOA} 100+\mathrm{a} 1000 \cdot \mathrm{SOA} 1000 \\
\mathrm{ISO}+\mathrm{O} 3 \rightarrow 0.58 \mathrm{HCHO}+0.10 \mathrm{ACO} 3+0.14 \mathrm{CO}+0.28 \\
\mathrm{ORA} 1+0.25 \quad \mathrm{HO}_{2}+0.08 \quad \mathrm{MO}_{2}+0.25 \quad \mathrm{HO}+0.09 \\
\mathrm{H}_{2} \mathrm{O}_{2}+0.65 \mathrm{MACR}+0.1(\mathrm{a} 1 \cdot \mathrm{SOA} 1+\mathrm{a} 10 \cdot \mathrm{SOA} 10+\mathrm{a} 100 \\
\cdot \mathrm{SOA} 100+\mathrm{a} 1000 \cdot \mathrm{SOA} 1000)\end{array}$ & 0.009 & 0.03 & 0.015 & 0 \\
\hline API & a-Pinene & $\begin{array}{l}\mathrm{API}+\mathrm{OH} \rightarrow \mathrm{a} 1 \cdot \mathrm{SOA} 1+\mathrm{a} 10 \cdot \mathrm{SOA} 10+\mathrm{a} 100 \\
\mathrm{SOA} 100+\mathrm{a} 1000 \cdot \mathrm{SOA} 1000 \\
\mathrm{API}+\mathrm{O} 3 \rightarrow 0.65 \quad \mathrm{ALD}+0.53 \quad \mathrm{KET}+0.14 \quad \mathrm{CO}+0.20 \\
(\mathrm{a} 1 \cdot \mathrm{SOA} 1+\mathrm{a} 10 \cdot \mathrm{SOA} 10+\mathrm{a} 100 \cdot \mathrm{SOA} 100+\mathrm{a} 1000 \\
\mathrm{SOA} 1000)+0.42 \quad(\mathrm{a} 1 \cdot \mathrm{SOA} 1+\mathrm{a} 10 \cdot \mathrm{SOA} 10+\mathrm{a} 100 \\
\mathrm{SOA} 100+\mathrm{a} 1000 \cdot \mathrm{SOA} 1000)+0.85 \mathrm{HO}+0.10 \mathrm{HO}_{2}+0.02 \\
\mathrm{H}_{2} \mathrm{O}_{2} \\
\mathrm{API}+\mathrm{MO}_{3} \rightarrow \text { a1 } \quad \mathrm{SOA} 1+\mathrm{a} 10 \cdot \mathrm{SOA} 10+\mathrm{a} 100 \\
\mathrm{SOA} 100+\mathrm{a} 1000 \cdot \mathrm{SOA} 1000\end{array}$ & 0.10725 & 0.0918 & 0.3585 & 0.6075 \\
\hline LIM & Limonene & $\begin{array}{l}\mathrm{LIM}+\mathrm{OH} \rightarrow \mathrm{a} 1 \cdot \mathrm{SOA} 1+\mathrm{a} 10 \cdot \mathrm{SOA} 10+\mathrm{a} 100 \\
\mathrm{SOA} 100+\mathrm{a} 1000 \cdot \mathrm{SOA} 1000 \\
\mathrm{LIM}+\mathrm{O} 3 \rightarrow 0.04 \mathrm{HCHO}+0.46 \mathrm{OLT}+0.14 \mathrm{CO}+0.16 \\
(\mathrm{a} 1 \cdot \mathrm{SOA} 1+\mathrm{a} 10 \cdot \mathrm{SOA} 10+\mathrm{a} 100 \cdot \mathrm{SOA} 100+\mathrm{a} 1000 \\
\mathrm{SOA} 1000)+0.42 \quad(\mathrm{a} 1 \cdot \mathrm{SOA} 1+\mathrm{a} 10 \cdot \mathrm{SOA} 10+\mathrm{a} 100 \\
\mathrm{SOA} 100+\mathrm{a} 1000 \cdot \mathrm{SOA} 1000)+0.85 \mathrm{OH}+0.10 \mathrm{HO}_{2}+0.02 \\
\mathrm{H}_{2} \mathrm{O}_{2}+0.79 \mathrm{MACR}+0.01 \mathrm{ORA} 1+0.07 \mathrm{ORA} 2 \\
\mathrm{LIM}+\mathrm{MO}_{3} \rightarrow \mathrm{a} 1 \cdot \mathrm{SOA} 1+\mathrm{a} 10 \cdot \mathrm{SOA} 10+\mathrm{a} 100 \\
\mathrm{SOA} 100+\mathrm{a} 1000 \cdot \mathrm{SOA} 1000\end{array}$ & 0.10725 & 0.0918 & 0.3585 & 0.6075 \\
\hline
\end{tabular}

\footnotetext{
* The saturation concentrations $\left(\mathrm{C}^{*}\right.$ ) of these species are $1,10,100,1000 \mu \mathrm{g} \mathrm{m}^{-3}$, respectively, at $298 \mathrm{~K}$ (Lane at al., 2008 ). Aerosol density is assumed to be $1.4 \mathrm{~g} \mathrm{~cm}^{-3}$.
} ** Isoprene species and reactions are only treated, when COSMO-ART is coupled with the four-product VBS scheme. 
similar volatilities can have different properties and reactivities (Donahue et al., 2012). To cope with this deficiency, a two-dimensional VBS scheme is developed, which uses the degree of oxidation as a second coordinate (Donahue et al., 2011). However, when tested against measurements in Europe it was found that the simple one-dimensional scheme had as good a performance as any of the more complex two dimensional VBS schemes probably due to uncertainties in our understanding of SOA evolution in the atmosphere (Murphy et al., 2012).

The four SOA bins of the current VBS approach represent both anthropogenic and biogenic species, unlike all aforementioned studies. By this approximation, the total number of SOA species is halved when COSMO-ART is coupled with the VBS, compared to using SORGAM. This is better suited for computationally expensive models such as COSMO-ART running with cloud-aerosol-meteorology coupled. The quantification of the contribution of each type of source requires additional simulations, but is still feasible and is presented in Sect. 4.4.5.

Both OA modules assume that the semi-volatile organics in the gas and particulate phases are in thermodynamic equilibrium. The organic particulate phase is assumed to be a pseudo-ideal solution. A vaporization enthalpy of $\Delta H_{\text {vap }}=75 \mathrm{~kJ} \mathrm{~mol}^{-1}$ is used for all semi-volatile species in the VBS module.

One of the most important differences between SORGAM and VBS is the treatment of SOA chemical aging: SORGAM simulates just the first generation of chemistry, while the VBS assumes that SOA compounds continue to react in the gas phase with the $\mathrm{OH}$ radical. These chemical reactions can lead to continued SOA formation even after complete precursor consumption. This chemical aging process becomes a major SOA source in most applications of the VBS approach (Murphy and Pandis, 2010). By these reactions, which use an aging rate constant of $k=2.5 \times 10^{-12} \mathrm{~cm}^{3} \mathrm{~mol}^{-1} \mathrm{~s}^{-1}$, mass from one volatility bin, modestly increased to account for the added oxygen ( $7.5 \%$ per reaction), is transferred to a bin with less volatility (Murphy et al., 2011). The volatility of those bins differs by one order of magnitude. Such a decrease in volatility per oxidation is regarded a conservative estimate (Robinson et al., 2007), because the drop in vapor pressure is typically much larger for traditional SOA precursors (Lim and Ziemann, 2005). Hodzic et al. (2010) showed that the addition of $40 \%$ oxygen in mass and the drop of two orders of magnitude in volatility upon each oxidation step are found to improve oxygen to carbon atomic ratio predictions, though lead to unrealistically high SOA production. Nevertheless, a number of complex and more realistic schemes has been recently tested and showed that a one-volatility bin shift scheme resulted in the best agreement with the observations (Murphy et al., 2012).

The overall rate of this aging process, as simulated in the current implementation of the VBS, is proportional to the gas-phase concentrations of the SOA compounds. As their

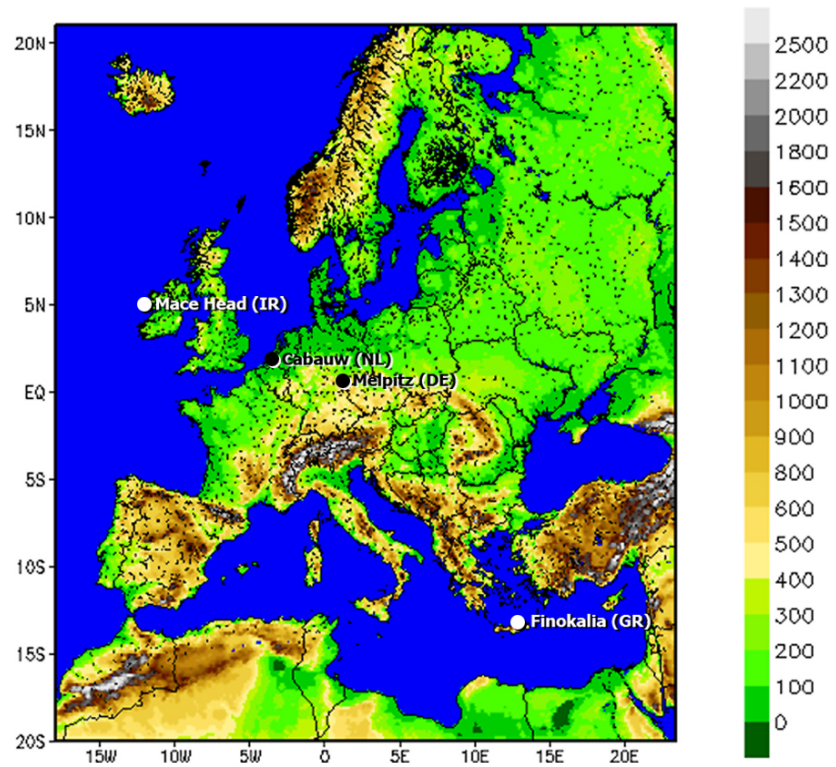

Fig. 1. COSMO-ART application domain and monitoring sites. Outside ticks at 5 degree intervals in rotated geographical coordinates. Colors correspond to elevation using $100 \mathrm{~m}$ intervals (map source: http://www.cosmo-model.org/content/tasks/ operational/dwd/default_eu.htm.)

volatility is reduced, their partitioning shifts towards the particulate phase and the aging rate slows down. This process effectively stops when the SOA compounds are in volatility bins with effective concentrations much lower than the ambient OA concentration.

POA components are treated as non-volatile in the COSMO-ART VBS approach, unlike other studies (Shrivastava et al., 2008; Tsimpidi et al., 2010; 2011). A potential shortcoming of this assumption is the under-prediction of OOA mass downwind urban areas, because semi-volatile organics associated with combustion emissions, and often measured as POA, will age and contribute to OOA levels.

\section{Application}

Simulations are performed over Europe for May 2008, when continuous and high temporal resolution measurements from various sites are available. The simulation area (Fig. 1) is covered by a grid $(332 \times 328$ cells $)$ with a horizontal resolution of $14 \mathrm{~km}$. Vertically, there are 40 layers extending to $20 \mathrm{~km}$, with the first layer being approximately $20 \mathrm{~m}$ thick. The meteorological initial and boundary conditions are obtained by the GME global model (Majewski et al., 2002) with an update frequency of $6 \mathrm{~h}$. Boundary data for gas-phase species (carbon monoxide: $\mathrm{CO}$, nitric acid: $\mathrm{HNO}_{3}$, ammonia: $\mathrm{NH}_{3}$, nitrogen oxides: $\mathrm{NO}_{\mathrm{x}}=\mathrm{NO}+$ nitrogen dioxide: $\mathrm{NO}_{2}, \mathrm{NO}_{3}$, sulfur dioxide: $\mathrm{SO}_{2}$, ozone: $\mathrm{O}_{3}$, non-methane volatile organic compounds: NMVOC), are provided through 
Table 2. Description of modeling scenarios performed by COSMO-ART application over Europe during May 2008. All scenarios except for no 1 and 3 are performed using the VBS approach.

\begin{tabular}{|c|c|c|c|c|}
\hline Scenario & $\begin{array}{l}\text { Simulation dates } \\
\text { (May 2008) }\end{array}$ & Scenario's Description & Objective & $\begin{array}{l}\text { Analysis } \\
\text { Section }\end{array}$ \\
\hline Base-case & 1 to 31 & VBS approach $^{1}$ & OA performance over Europe & 4.2 \\
\hline 1 & 1 to 31 & SOA chemistry is switched off & Direct radiative effects of SOA & 4.3 \\
\hline 2 & 1 to 31 & zero SOA boundary conditions 1 & $\begin{array}{l}\text { Impact of SOA boundary con- } \\
\text { ditions on OA predictions }\end{array}$ & 4.4 .1 \\
\hline 3 & 1 to 10 & SORGAM module & $\begin{array}{l}\text { SOA chemical module inter- } \\
\text { comparison }\end{array}$ & 4.4 .2 \\
\hline 4 & 1 to 31 & VBS approach $^{2}$ & $\begin{array}{l}\text { Sensitivity of SOA formation } \\
\text { on constant parameters }\end{array}$ & 4.4 .3 \\
\hline 5 & 16 to 20 & High-NOx regime $^{2}$ & $\begin{array}{l}\text { Sensitivity of SOA formation } \\
\text { on constant parameters }\end{array}$ & 4.4 .3 \\
\hline 6 & 1 to 10 & SOA aging is not a sink for $\mathrm{OH}^{1}$ & $\begin{array}{l}\text { Impact of SOA oxidation on } \\
\text { inorganic aerosol chemistry }\end{array}$ & 4.4 .4 \\
\hline 7 & 11 to 15 & $\begin{array}{l}\text { biogenic VOCs oxidation is not a } \\
\text { source for SOA }\end{array}$ & $\begin{array}{l}\text { Anthropogenic vs. biogenic } \\
\text { SOA sources }\end{array}$ & 4.4 .5 \\
\hline
\end{tabular}

1 Aging constant: $k=2.5 \times 10^{-12} \mathrm{~cm}^{3} \mathrm{~mol}^{-1} \mathrm{~s}^{-1}$, Enthalpy of vaporization: $\Delta \mathrm{H}_{\mathrm{vap}}=75 \mathrm{~kJ} \mathrm{~mol}^{-1}$.

2 Aging constant: $k=1 \times 10^{-11} \mathrm{~cm}^{3} \mathrm{~mol}^{-1} \mathrm{~s}^{-1}$, Enthalpy of vaporization: $\Delta \mathrm{H}_{\mathrm{vap}}=30 \mathrm{~kJ} \mathrm{~mol}^{-1}$.

simulations of the MOZART global model (Emmons et al., 2010) with an update frequency of $6 \mathrm{~h}$. For aerosol mass, constant boundary concentrations are used for the secondary species in the aged modes: $1 \mu \mathrm{g} \mathrm{m}^{-3}$ for sulfates, $0.1 \mu \mathrm{g} \mathrm{m} \mathrm{m}^{-3}$ for nitrates, $0.37 \mu \mathrm{g} \mathrm{m}^{-3}$ for ammonium and $1 \mu \mathrm{g} \mathrm{m}^{-3}$ for SOA in the surface layer (number concentrations are calculated consistently). The effective saturation concentration of the latter is assumed as 1 (half of the mass) and $10 \mu \mathrm{g} \mathrm{m}^{-3}$. All values are vertically decreased following the air density profile. Anthropogenic emissions used $\left(\mathrm{CO}, \mathrm{NH}_{3}, \mathrm{NO}_{2}\right.$, $\mathrm{NO}$, sulfuric acid, $\mathrm{SO}_{2}$, NMVOC, elemental and organic carbon, primary sulfate) are based on the TNO/MACC inventory (Kuenen et al., 2011; Denier van der Gon et al., 2010). Hourly emission values for two representative diurnal cycles (weekday and weekend) are derived from TNO/MACC values of 2007, scaled to 2008 employing per-species country totals as reported to EMEP (http://www.emep.int). A detailed description of the emission treatment for COSMO-ART can be found in Knote et al. (2011). The one month period is covered by 5-day successive simulations, in order to reinitialize meteorological fields with the GME analysis data. The first 2 days of May are used as a spin-up, to minimize the effect of initial conditions for gases and aerosol on the model predictions.

\subsection{Model scenarios}

May 2008 has been identified as a significant pollution episode with high secondary aerosol levels in North-Western Europe, causing a large decrease in the aerosol direct radiative forcing. Thus, this period is an ideal case to test regional and global climate model representations of the Eu- ropean area (Morgan et al., 2010a). In order to quantify the direct radiative forcing due to SOA formation in COSMOART, an additional one-month simulation was performed with SOA chemistry switched off (scenario 1). Deviations from the baseline predictions for several atmospheric parameters (cloud cover, radiation, air temperature etc) reflect changes due to SOA formation over Europe (Sect. 4.3).

In addition to the baseline one-month simulation and scenario 1 (no SOA formation) six additional simulations were carried out to evaluate the role of SOA boundary conditions and SOA modeling approach on the COSMO-ART results. A summary of all simulations can be found in Table 2 .

As a result of its long lifetime, SOA from the boundaries of the domain can significantly affect not only the adjacent areas, but also central Europe. Model differences between the baseline simulation and a configuration using zero SOA concentration at the boundaries (scenario 2) quantify this effect, and are discussed in Sect. 4.4.1.

A model inter-comparison is presented in Sect. 4.4.2., and is two-fold: a SOA module inter-comparison is performed, in order to quantify and explain the differences in OA concentration predictions between the SORGAM (scenario 3) and the VBS approach (base-case). Comparisons are presented for the site of Cabauw (Netherlands). Then, an OA predictions inter-comparison is presented against results by the chemical transport model (CTM) PMCAMx during the same period. Description of this model can be found in several publications (Karydis et al., 2010; Fountoukis et al., 2011), while the PMCAMx treatment of aerosol chemistry using the VBS is described by Tsimpidi et al. (2010). The PMCAMx application for May 2008 covers approximately the same area as the COSMO-ART application, but 
the horizontal resolution is coarser $(36 \mathrm{~km})$ and the vertical extent is shallower (14 vertical layers covering approximately $6 \mathrm{~km}$ height). The depth of the surface layer is $55 \mathrm{~m}$. Meteorological fields are provided by offline WRF simulations, since PMCAMx is a CTM. Anthropogenic, biogenic, sea-salt and wildfire emissions are provided by different sources/models than for COSMO-ART, as explained in Fountoukis et al. (2011). Boundary conditions for gaseous and aerosol pollutants are constant in space and time and, in case of secondary species, similar to COSMO-ART prescriptions. The first two days of the simulated period are again used as the model's spin up. The main differences to the COSMO-ART and VBS coupling, is that in PMCAMx primary semi-volatile organics and anthropogenic intermediate volatility compounds are aged in the gas phase $\left(k=4 \times 10^{-11} \mathrm{~cm}^{3} \mathrm{~mol}^{-1} \mathrm{~s}^{-1}\right.$ ), the rate constant used for anthropogenic SOA is higher $\left(k=1 \times 10^{-11} \mathrm{~cm}^{3} \mathrm{~mol}^{-1} \mathrm{~s}^{-1}\right)$, and the aging of biogenic SOA is assumed to result in a zero net change of its average volatility.

Uncertain parameters of the COSMO-ART SOA model include the aging rate of SOA components along with their vaporization enthalpy. In order to bound the model predictions for plausible ranges of these parameters, a sensitivity study (scenario 4 ) is conducted using the faster and commonly used aging rate constant of $k=1 \times 10^{-11} \mathrm{~cm}^{3} \mathrm{~mol}^{-1} \mathrm{~s}^{-1}$ (Murphy and Pandis, 2009; 2010; Farina et al., 2010; Fountoukis et al., 2011). This is coupled to an effective vaporization enthalpy commonly used in VBS modules $\left(\Delta H_{\mathrm{vap}}=30 \mathrm{~kJ} \mathrm{~mol}^{-1}\right)$, based on fitting of smog chamber results of SOA formation (Lane et al., 2008). The application of the currently used aerosol yields is also tested against lower values (scenario 5), occurring in a high- $\mathrm{NO}_{\mathrm{x}}$ regime (Murphy and Pandis, 2009). This configuration is based upon the aforementioned $k$ and $\Delta H_{\text {vap }}$ values.The corresponding results for $\mathrm{OA}$ and their comparison to the base case are presented in Sect. 4.4.3.

The chemical aging of SOA in the atmosphere can act as a sink of hydroxyl radicals. Thus, by incorporating this process into modeling, secondary inorganic aerosol (SIA) production can be influenced. Changes in sulfate, nitrate and ammonium aerosol (the main components of SIA) due to SOA oxidation are presented in the Sect. 4.4.4, after applying the model without aging being a net sink for $\mathrm{OH}$ (scenario 6).

Finally, the contribution of biogenic VOC sources on OA concentrations over Europe is estimated comparing the OA concentration field in the baseline scenario with that of a simulation (scenario 7) neglecting biogenic SOA formation (Sect. 4.4.5). The SOA fraction which corresponds to the organic mass from outside the domain (SOA boundary concentrations) is regarded as non-anthropogenic, thus also excluded from scenario 7 .

\subsection{Measurements}

During May 2008 an intensive measurement campaign was performed in Europe as part of the EUCAARI project (Kul- mala et al., 2011). Model results are compared with hourly mean values from four measurement ground sites: Cabauw (The Netherlands), Finokalia (Greece), Mace Head (Ireland) and Melpitz (Germany). All observation sites are not directly influenced by local sources, thus are representative of regional pollution (Fig. 1).

The Cabauw site $\left(51.971^{\circ} \mathrm{N}, 4.927^{\circ} \mathrm{E}\right)$ is located in a rural, agricultural region. The site provided measurements for total OA, sulfates, nitrate, and ammonium for the period of 3 to 29 May 2008. The instrument used was a HR-ToFAMS (Morgan et al., 2010b). The Finokalia sampling station $\left(35.33^{\circ} \mathrm{N}, 25.67^{\circ} \mathrm{E}\right)$ is located at a remote, coastal area in the Eastern Mediterranean. The species measured are the same as in Cabauw, but the period available is shorter ( 8 to 29 May 2008). The instrument used was a Q-AMS (Hildebrandt et al., 2010). Atmospheric temperature, humidity, wind and radiation are also available for the same period. Mace Head $\left(53.32^{\circ} \mathrm{N}, 9.88^{\circ} \mathrm{W}\right)$ is a coastal atmospheric research station suitable for studies of long-range transport. A HR-ToF-AMS was used to measure mass concentrations of organics during 23 to 29 May 2008. The site in Melpitz $\left(12.93^{\circ}\right.$ E, $\left.51.54^{\circ} \mathrm{N}\right)$ is located in flat, agricultural terrain and can be regarded as representative of the regional central European aerosol. OA measurements (from a HR-ToF-AMS) are available during the period of 23 May to 9 June 2008. Atmospheric temperature, humidity, wind, radiation, pressure and precipitation are also available for the same period.

\subsection{Description of meteorology}

The meteorological regime of May 2008 over Europe has been analyzed in several publications (Morgan et al., 2010a; Morgan et al., 2010b; Pikridas et al., 2010; Hamburger et al., 2011). Hereafter, a general description relevant to the current study is given.

The first half of May was dominated by an anticyclone blocking event, centered mainly over the Benelux states, the northern part of Germany and Denmark. Starting from 12 May, high pressure conditions prevailed over the North East Atlantic, and Central and Eastern continental Europe. This regime lasted until 16 May and combined with the passage of cyclones over Southern Europe resulted in a westward transport of continental air masses towards Northwestern Europe. During 16 to 18 May, a trough evolved over Central Europe. Frontal systems associated with the trough changed the flow regime from westward to eastward air mass transport. Arctic air masses were advected via the North Sea towards continental Europe. The flow regime over Central Europe changed again its direction beginning on 18 May with the onset of an anticyclonic North-Easterly pattern. Wind directions over Central Europe turned back to east after 21 May. During 19 to 21 May, a Saharan dust event was observed in Southern Europe. 

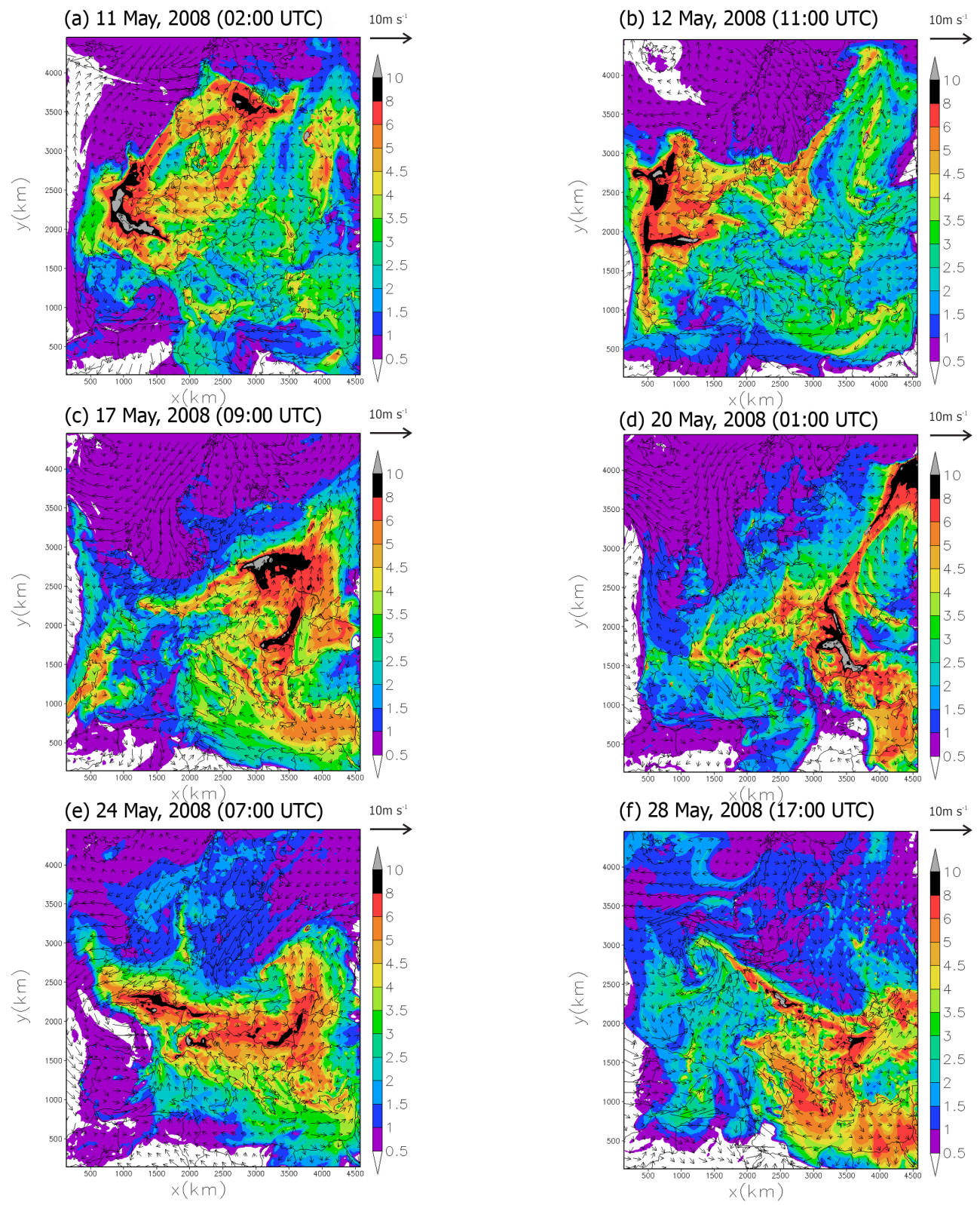

Fig. 2. Spatial distribution of surface organic aerosol (OA) concentrations $\left(\mu \mathrm{g} \mathrm{m}^{-3}\right.$ ) over Europe, on May 2008, (date, time in UTC): (a) 11, 02:00, (b) 12, 11:00, (c) 17, 09:00, (d) 20, 01:00, (e) 24, 07:00, and (f) 28, 17:00 The arrows indicate surface hourly wind fields. All fields are COSMO-ART predictions.

\section{Results}

The modeling results are presented in four subsections. First, representative hourly OA concentration fields are presented and analyzed along with the online wind field predictions and observational findings from previous studies (Sect. 4.1). Then, OA predictions are evaluated against ground measurement data (Sect. 4.2). The next section (Sect. 4.3) provides insights into the direct radiative effects related to SOA chemistry over Europe for May 2008. In order to investigate further SOA chemistry, a discussion on model predictions from the sensitivity studies described in Sect. 3.1 is given in Sect. 4.4.

\subsection{Simulated OA concentrations}

High OA concentrations extend over large regions often far from their emission areas during the whole simulation period. This is because SOA formation and aging take place over hours or days during the advection of air masses away from their sources. Aircraft measurements of high levels of oxidized OA and low levels of fresh OA during May 
(a)

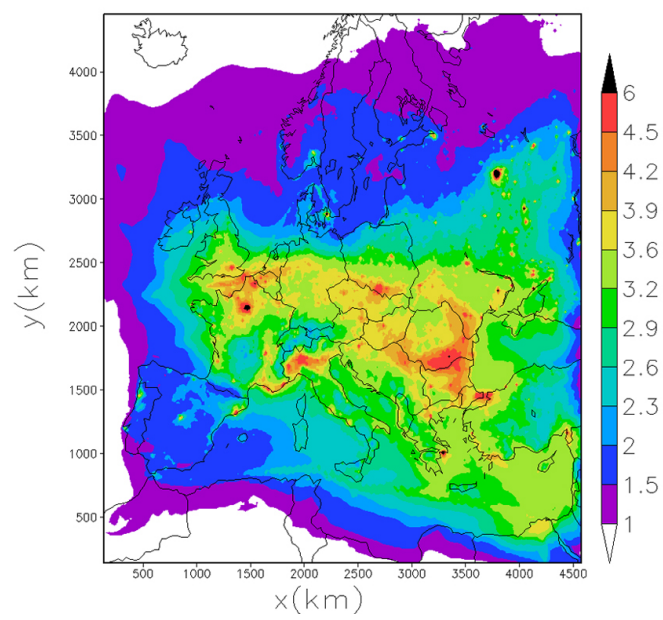

(b)

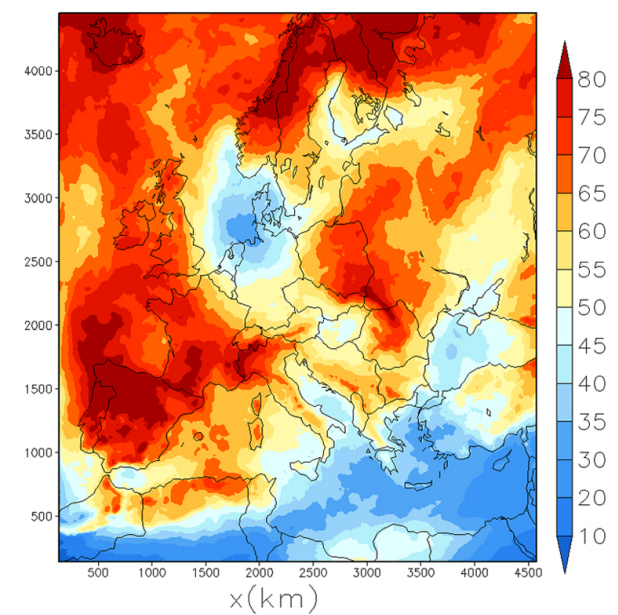

Fig. 3. Spatial distribution of mean monthly: (a) organic aerosol (OA) concentrations $\left(\mu \mathrm{g} \mathrm{m}^{-3}\right)$ and (b) total cloud cover (\%), as predicted by COSMO-ART, during May 2008 over Europe.

2008 (Morgan et al., 2010b) are also indicative of the photochemical processing of the OA over Europe, as predicted by COSMO-ART.

The anticyclonic conditions over central Europe (Sect. 3.3) are clearly reproduced by the current simulation and cause OA accumulation within the anticyclone (Fig. 2a). Pollution peaks inside the boundaries of the anticyclone are linked to the absence of clouds and precipitation and the inhibition of mixing of particles from the boundary layer into the free troposphere (Hamburger et al., 2011). Maximum hourly OA values reach $10 \mu \mathrm{g} \mathrm{m}^{-3}$ during this blocking event. After 12 May, when the anticyclone is formed over North East Atlantic, European continental air masses are transported westerly and lead to a pollution event over the Atlantic Ocean (Fig. 2b). Hourly OA concentrations over this area are well above $5 \mu \mathrm{g} \mathrm{m}^{-3}$.

The change in the wind field during 16 to 18 May (Sect. 3.3), caused advection of clean air masses (hourly OA mass values less than $1 \mu \mathrm{g} \mathrm{m}^{-3}$ ) via the North Sea towards continental Europe. This flow has been described by Hamburger et al. (2011) and is successfully represented by COSMO-ART (Fig. 2c). The northwestern transport of OA towards the Eastern Mediterranean during the same period from continental Greece is consistent with calculations with the particle dispersion model FLEXPART (Pikridas et al., 2010). According to measurement analysis of Hildebrandt et al. (2010), OA was diluted and highly aged by the time air masses reached Finokalia. This explains the elevated OA predictions over the sea (hourly values more than $5 \mu \mathrm{g} \mathrm{m}^{-3}$ ) when compared to the less processed air masses over continental Greece (hourly values less than $5 \mu \mathrm{g} \mathrm{m}^{-3}$ ).

This event was followed by an Africa air mass intrusion (19 to 21 May) (Pikridas et al., 2010). Predictions by COSMO-ART confirm this flow regime, which is accompa- nied with low OA values (up to $1 \mu \mathrm{g} \mathrm{m}^{-3}$ ), because African organic aerosol sources are not included in the current application (Fig. 2d). A detailed study on this event, as simulated by COSMO-ART, has been recently published (Bangert et al., 2012).

The change of wind direction to east after 21 May over central Europe led to an increase in concentrations over northwestern Europe (Hamburger et al., 2011). This is reproduced by the simulation (hourly OA mass values of 5 to $10 \mu \mathrm{g} \mathrm{m}^{-3}$ ) (Fig. 2e). From then on, the wind field over central Europe becomes weaker, and its eastern component transfers air masses from Poland towards Germany (Fig. 2f). $\mathrm{OA}$ levels within these aerosol masses reach $10 \mu \mathrm{g} \mathrm{m}^{-3}$. The strong influence of long-range transport of secondary particle masses from the east is systematically observed over this area (Spindler et al., 2010).

The geographical distribution of monthly mean OA produced by this study (Fig. 3a) is compared to fields presented in earlier model studies over Europe that applied VBS. For most parts of the European continent, the calculated total OA in fine particles both by EMEP (Bergström et al., 2012) and COSMO-ART (current study) is around $2-3 \mu \mathrm{g} \mathrm{m}^{-3}$, while PMCAMx (Fountoukis et al., 2011) predictions are in the 1.5 to $5 \mu \mathrm{g} \mathrm{m}^{-3}$ range. Another similarity between the current study and EMEP outputs is the elevated OA values over the Mediterranean area. Similar OA peaks are predicted by PMCAMx and COSMO-ART over the English Channel, which are not shown in EMEP results. Overall, OA predictions by these studies lie in similar levels. Since the study by Bergström et al. (2012) does not include the year 2008, a direct comparison with the results of the current study is not possible, but PMCAMx results are discussed further in Sect. 4.4.2. 
Table 3. Prediction skill metrics of COSMO-ART hourly ground total $\mathrm{PM}_{1}$ OA concentration predictions against measurements from 4 stations (Cabauw, Finokalia, Mace Head, Melpitz) during the EUCAARI campaign in May 2008.

\begin{tabular}{|c|c|c|c|c|c|c|}
\hline Site & $\begin{array}{l}\text { Mean predicted } \\
\qquad\left(\mu \mathrm{g} \mathrm{m}^{-3}\right)\end{array}$ & $\begin{array}{l}\text { Mean observed } \\
\qquad\left(\mu \mathrm{g} \mathrm{m}^{-3}\right)\end{array}$ & $\begin{array}{l}\text { MFB (\%) } \\
\text { (Eq. (1)) }\end{array}$ & $\begin{array}{l}\text { MFE (\%) } \\
(\text { Eq. (2)) }\end{array}$ & $r^{*}$ & $\begin{array}{l}\text { No of } \\
\text { values }\end{array}$ \\
\hline Cabauw (The Netherlands) & 3.6 & 4.2 & -12 & 33 & 0.66 & 622 \\
\hline Mace Head (Ireland) & 1.3 & 2.4 & -48 & 51 & 0.37 & 336 \\
\hline Finokalia (Greece) & 3.1 & 2.5 & 14 & 51 & 0.36 & 490 \\
\hline Melpitz (Germany) & 4.3 & 5.1 & -30 & 56 & 0.1 & 155 \\
\hline Average & & & -13 & 45 & 0.56 & 1603 \\
\hline
\end{tabular}
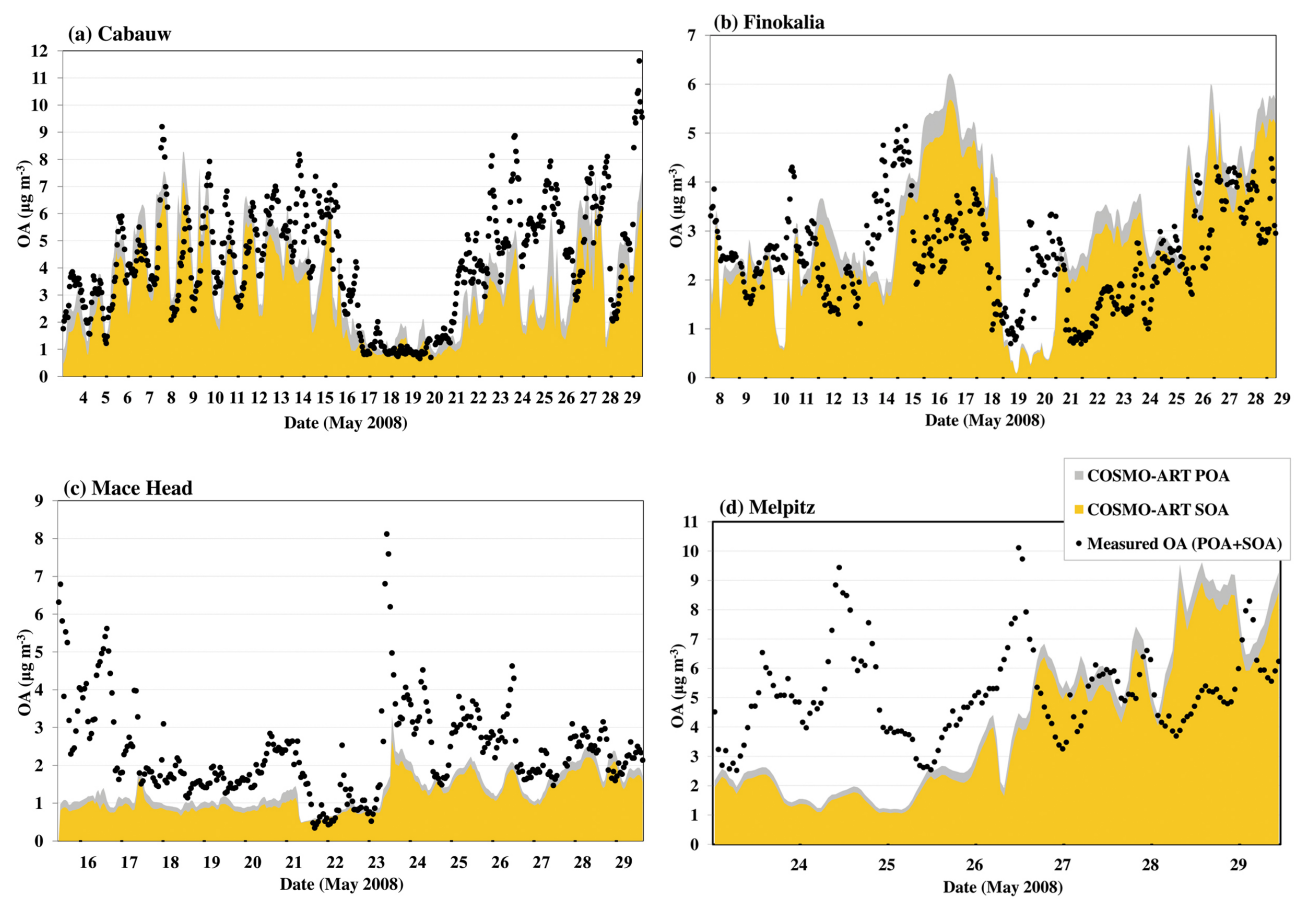

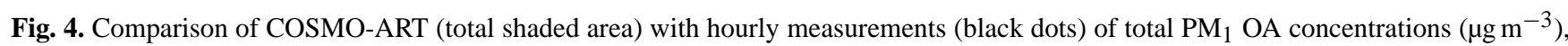
during the EUCAARI campaign, over: (a) Cabauw, (b) Finokalia, (c) Mace Head and (d) Melpitz; the legend applies for all preceding graphs. The contribution of COSMO-ART predicted POA (in grey) and SOA (in yellow) to the total $\mathrm{PM}_{1}$ OA mass is also shown. Dates at the $\mathrm{x}$ axis are marked at 12:00 UTC.

\subsection{OA performance of COSMO-ART}

While the previous paragraph largely proves the model's efficiency to qualitatively reproduce the atmospheric circulation observed over the whole European area during May 2008, this section is an attempt to evaluate local OA predictions in a quantitative manner. Time series of $\mathrm{PM}_{1} \mathrm{OA}$ measured in the four stations and predicted by COSMO-ART during the EUCAARI May 2008 campaign are presented in Fig. 4 and monthly mean values together with performance metrics are given in Table 3.

Average $\mathrm{PM}_{1}$ OA measurements are around 5.1 and $4.2 \mu \mathrm{g} \mathrm{m}^{-3}$ for the central European sites in Germany and the Netherlands, respectively, while the peripheral sites of Finokalia and Mace Head exhibit lower values (3.1 and $1.3 \mu \mathrm{g} \mathrm{m}^{-3}$, respectively). The corresponding predicted values are $4.3,3.6,2.5$ and $2.4 \mu \mathrm{g} \mathrm{m}^{-3}$, respectively. The prediction skill of COSMO-ART $\mathrm{PM}_{1}$ OA mass is quantified in terms of the Mean Fractional Bias ( MFB) and Mean Fractional Error (MFE) metrics (Boylan and Russell, 2006):

$\mathrm{MFB}=\frac{2}{N} \sum_{i=1}^{N} \frac{C_{\mathrm{m}}-C_{\mathrm{o}}}{C_{\mathrm{m}}+C_{\mathrm{o}}} \quad \mathrm{MFE}=\frac{2}{N} \sum_{i=1}^{N} \frac{\left|C_{\mathrm{m}}-C_{\mathrm{o}}\right|}{C_{\mathrm{m}}+C_{\mathrm{o}}}$

where $C_{\mathrm{m}}$ is the modeled and $C_{\mathrm{o}}$ is the observed hourly value for $\mathrm{PM}_{1} \mathrm{OA}$ concentration $\left(\mu \mathrm{g} \mathrm{m}^{-3}\right)$ at the site $i$ and $N$ the 
number of estimate-observation pairs drawn from all valid monitoring station data for the comparison time period of interest.

According to the proposed model performance goal $(\mathrm{MFE} \leq 50 \%$ and $\mathrm{MFB} \leq \pm 30 \%)$ and criteria $(\mathrm{MFE} \leq 75 \%$ and MFB $\leq \pm 60 \%$ ), the level of accuracy of COSMO-ART is satisfactory. More specifically, OA predictions for Mace Head, Finokalia and Melpitz are acceptable (criteria are met) while the model performs in Cabauw at the best level of accuracy (goal is met).

Overall, both the hourly and the diurnal variation of organics are well captured by the model at all four aforementioned sites. Specifically, the observed daily cycle of OA over Cabauw (Fig. 4a) is successfully reproduced. The OA increases during the afternoon due to the photochemical aging of aerosol combined to mixing of aged OA from aloft. The OA is high during nighttime due to lower mixing height and partitioning of organic vapors from the gas to the particle phase due to lower temperatures. During the first half of May and due to the anticyclonic event, polluted air masses are predicted to be transported towards Cabauw from North Germany (Fig. 2a), which is consistent with the calculated air mass trajectories using the ECMWF wind field (Hamburger et al., 2011). The low OA concentrations observed and predicted during 16 to 21 May are caused by the transport of Arctic masses towards Europe (Fig. 2c). Long-range transport of masses from central Europe causes an increase in OA concentrations after the 21st of May.

A common feature of predictions and observations over Finokalia is the absence of a clear daily cycle of OA (Fig. 4b). This is due to the lack of local or nearby sources of OA and the aged nature of the OA. The highest OA concentrations occur around the middle of the month and originate from Athens and the rest of continental Greece (Fig. 2c). During this period, lower wind speeds are predicted and observed (Pikridas et al., 2010). This leads to an increased accumulation of organics in the atmosphere, which are intensively aged and added to the next day's SOA formation. This episode is captured though over-predicted by COSMO-ART. The Africa air mass intrusion that follows (20 to 21 May) leads to OA underestimation. According to Hildebrandt et al. (2010), the air mass transported from the south was possibly influenced by major cities in Africa. This organic content of aerosol is not represented by the boundary conditions applied in the current simulations (Sect. 3.1) and emissions from African countries are not included in the inventory used in these simulations.

The diurnal variation of organics is moderately reproduced over Mace Head (Fig. 4c). A noticeable underestimation occurs during 16 to 17 May, when air masses arrive to Mace Head from the northeast (Hamburger et al., 2011). COSMO-ART shows that northeastern wind directions transfer organic-free air masses from the North Sea and the Scandinavian Peninsula (Fig. 2c). This could be related to a VOC or OA source not included in the emission inventory used.
Elevated OA masses from 23 until 26 May are shown both in measurements and model and originate from pollution sources at the continental Europe (Fig. 2e).

Noticeable discrepancies between hourly OA predictions and observations occur over Melpitz in the first days of the period of comparison (Fig. 4d). Although northeastern winds over central Europe (Hamburger et al., 2011) are found to cause high levels of OA over Melpitz on 24 May, predictions show that these winds transfer clean air masses towards Germany, Poland and the Czech republic during the same period (Fig. 2e). OA predictions are much lower than measurements during this event, implying again a possible source of organics missing from the emission database used, in European Russia north of Moscow. OA peaks after 26 May as air masses transported from Eastern Europe arrive at the site. OA over this area during this type of transport is usually underestimated by CTMs (Spindler et al., 2010). Nevertheless, COSMO-ART succeeds to reproduce the high OA values measured, but the strong spatial gradient of the predicted field (Fig. 2f), makes the point-to-grid comparison challenging and their temporal correlation weaker.

Oxygenated organic aerosol is predicted to account for 80 to $95 \%$ of the total $\mathrm{PM}_{1}$ organics, which is in line with measurement studies (Zhang et al., 2007; Morgan et al., 2010b; Hildebrandt et al., 2010). This shows the preponderance of atmospheric chemical transformations of organic matter over the freshly emitted organic aerosol. Measurements during May 2008 over Europe (Morgan et al., 2010b) indicate that POA typically contributed 5 to $20 \%$ to the regional OA burden. According to measurements of Hildebrandt et al. (2010), HOA at Finokalia was not present in detectable amounts. Likewise, COSMO-ART calculated the minimum POA amount of OA (5\%) over this site. However, comparisons at or close to urban areas may be less satisfactory, due to the chemical aging of some VOC components from combustion often counted as POA in emission datasets (Murphy and Pandis, 2009).

\subsection{SOA direct radiative effect}

The average changes on aerosol and its feedback, which are imposed by SOA simulated by the VBS scheme applied over Europe (base-case scenario) are summarized in Table 4. SOA is the major component of the additional aerosol mass (approximately $2 \mu \mathrm{g} \mathrm{m}^{-3}$ ) corresponding to more than $55 \%$ of total $\mathrm{PM}_{1}$ predicted by the baseline simulation. Besides SOA, increased sulfate and ammonium formation is found (nitrate mass is found negligible). This surplus to aerosol originates from the enhanced condensation onto a larger aerosol surface due to the organic mass, and results in an increase in the mean diameter of aerosol. This results in a $5 \%$ increase in total $\mathrm{PM}_{1}$. As a consequence, water uptake by aerosol is also enhanced (5\%). These mass and size changes in aerosol lead to a $15 \%$ increase of aerosol optical depth. As the aerosol scattering increases due to organics, sulfates, 
Table 4. Mean monthly differences (base-case - scenario 1) due to SOA chemistry during May 2008 over Europe. The simulations are performed by COSMO-ART and are described in Table 2.

\begin{tabular}{|c|c|c|c|}
\hline Parameter & Symbol & Absolute change & $\begin{array}{c}\text { Percentage } \\
\text { change }\end{array}$ \\
\hline Total $\mathrm{PM}_{1}$ concentration & $\Delta \mathrm{PM}_{1}$ & $2 \mu \mathrm{g} \mathrm{m}^{-3}$ & 51 \\
\hline Non-SOA PM 1 & $\Delta \mathrm{PM}_{1 \text { rest }}$ & $0.2 \mu \mathrm{g} \mathrm{m}^{-3}$ & 5 \\
\hline SOA concentrations & SOA & $1.8 \mu \mathrm{g} \mathrm{m}^{-3}$ & 100 \\
\hline Aitken mode mass concentration & $\Delta \mathrm{PM}_{\text {aitken }}$ & $0.0 \mu \mathrm{g} \mathrm{m}^{-3}$ & 1 \\
\hline Accumulation mode mass concentration & $\Delta \mathrm{PM}_{\mathrm{acc}}$ & $0.2 \mu \mathrm{g} \mathrm{m}^{-3}$ & 5 \\
\hline Aerosol optical depth at $550 \mathrm{~nm}$ & $\triangle \mathrm{AOD}$ & 0.05 & 13 \\
\hline Total cloud cover & $\Delta \mathrm{CC}$ & $-0.05 \%$ & 0 \\
\hline Total surface radiation & $\Delta s \mathrm{R}$ & $-1.2 \mathrm{~W} \mathrm{~m}^{-2}$ & $-20^{*}$ \\
\hline Short-wave surface radiation & $\Delta \mathrm{sSWR}$ & $-1.4 \mathrm{~W} \mathrm{~m}^{-2}$ & $-20^{*}$ \\
\hline Long-wave surface radiation & $\Delta \mathrm{sLWR}$ & $+0.2 \mathrm{~W} \mathrm{~m}^{-2}$ & $+20^{*}$ \\
\hline Temperature (at $2 \mathrm{~m}$ a.s.1.) & $\Delta T$ & -0.1 & $59^{*}$ \\
\hline
\end{tabular}

* This is the ratio of SOA to total aerosol effect on radiation and temperature.

(a) $\triangle \mathrm{CC}$

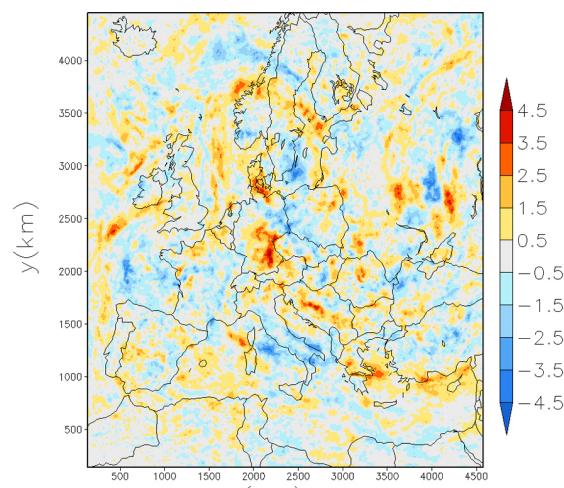

(c) $\Delta$ sLWR $\times(\mathrm{km})$

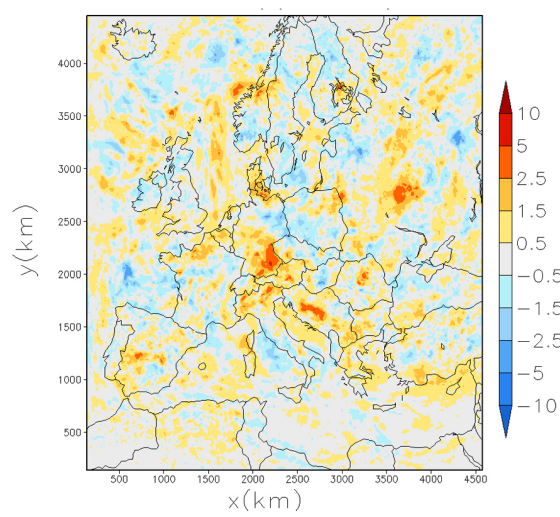

(b) $\triangle S S W R$

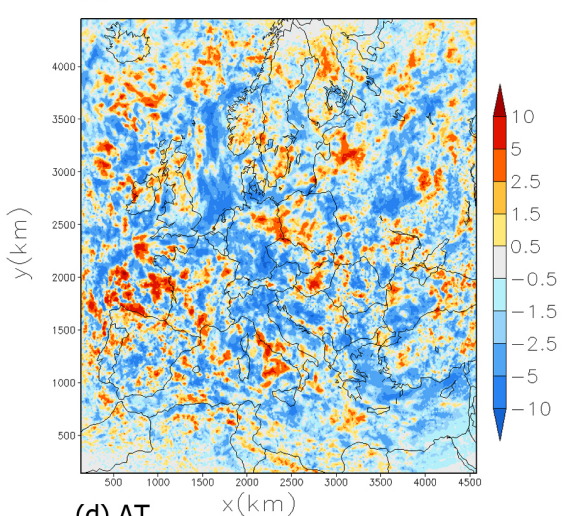

(d) $\Delta T$

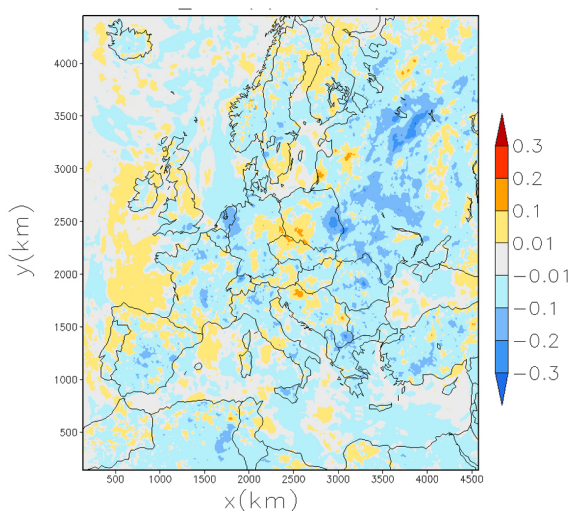

Fig. 5. Spatial distribution of mean monthly differences (base-case simulation - scenario 1) in: (a) total cloud cover ( $\Delta$ CC) (\%), (b) shortwave surface radiation $(\Delta \mathrm{sSWR})\left(\mathrm{W} \mathrm{m}^{-2}\right)$, (c) long-wave surface radiation $(\Delta \mathrm{sLWR})\left(\mathrm{W} \mathrm{m}^{-2}\right)$, and (d) temperature $(\Delta T$ at $2 \mathrm{~m}$ altitude) (K), due to SOA chemistry during May 2008 over Europe. The simulations are performed by COSMO-ART and are described in Table 2.

ammonium and water, the reflection of solar radiation back to space is also increased. The effect on the long wave radiation back to earth is much weaker, thus the net surface radiative forcing imposed by organic aerosol chemistry is negative. The predicted mean direct surface radiative cooling averaged over Europe is $-1.2 \mathrm{~W} \mathrm{~m}^{-2}$. for May 2008 and contributes approximately $20 \%$ to the total aerosol effect. Over certain areas (e.g. southeastern Germany, Fig. 5) the 
predicted radiative cooling is an order of magnitude stronger than the mean value of $-1.2 \mathrm{~W} \mathrm{~m}^{-2}$. The corresponding decrease in average temperature (at $2 \mathrm{~m}$ altitude) is calculated at $-0.1 \mathrm{~K}$. Maximum values of surface temperature reductions are around $-0.3 \mathrm{~K}$ over European Russia.

These values correspond to a polluted period compared to the rest of 2008 (Morgan et al., 2010b), thus probably represent an upper limit of the SOA effect. Moreover, they are the response to the forcing applied within the European area, but following Shindell and Faluvegi (2009) findings for black carbon and sulfates, forcing linked to organic aerosol mass over the tropics and the arctic is also expected to contribute to the total surface air temperature changes over Europe.

Simulations on the global scale have shown an annual mean SOA radiative cooling over Europe in the range of -0.25 to $-0.75 \mathrm{~W} \mathrm{~m}^{-2}$, when organic mass is up to $2 \mu \mathrm{g} \mathrm{m}^{-3}$, which is much lower than the measured values (up to $6 \mu \mathrm{g} \mathrm{m}^{-3}$ ) (Ming et al., 2005; Myhre et al., 2009; O'Donnell et al., 2011). To the best of our knowledge there do not exist any other publications on SOA direct radiative forcing over Europe on the regional scale. Nevertheless, the results of the current study are in line with the yearly averaged anthropogenic aerosol feedback over Europe $\left(\Delta \mathrm{sR}=-1\right.$ to $-3 \mathrm{~W} \mathrm{~m}^{-2}$ and $\Delta T=-0.1$ to $-0.2 \mathrm{~K}$ ), as calculated by a regional model (Zanis et al., 2012).

The SOA-imposed direct radiative forcing is affected not only by aerosol scattering radiation, but also partially by the semi-direct effect of cloud cover, which was abundant in the simulation period (Fig. 3b). The formation of convective clouds within each computational cell is highly sensitive to local air temperature, which is directly affected by the SOA mass, as shown above, and in turn affects aerosol radiative forcing. This nonlinear interaction among processes, results in a noisy spatial pattern of cloud cover (Fig. 5a). Contrary to the average regime described in the previous paragraph, in areas where the decrease of cloud cover reaches up to $5 \%$, short and long wave radiative forcings reach their highest $\left(+13 \mathrm{~W} \mathrm{~m}^{-2}\right)$ and lowest values $\left(-4 \mathrm{~W} \mathrm{~m}^{-2}\right)$, respectively (Fig. $5 \mathrm{~b}$ and c). These areas cover approximately $30 \%$ of the European domain, where a monthly average temperature increase of $0.2 \mathrm{~K}$ (at $2 \mathrm{~m}$ altitude) is predicted (Fig. 5d). This is already found in a previous study with COSMO-ART, where total-sky situations did not result in a homogeneously negative radiative forcing of aerosols, as during a cloud-free episode, but in smaller, even positive temperature changes, spotty and spatially uncorrelated to the forcing (Vogel et al., 2009).

The high spatial sensitivity of the cloud formation mechanism introduces some uncertainty in the spatially-resolved forcing, but it does not seem to affect the average regional radiation and temperature changes. Indeed, the sum of cloud cover changes over Europe due to SOA chemistry during May 2008 is found negligible (Table 4).

\subsection{Sensitivity analysis}

The results and analysis that follow are based on the scenarios 2 to 7 presented in Table 2 and described in Sect. 3.1.

\subsubsection{Impact of boundary conditions}

The OA that is transported into the European area from the boundaries of the modeling domain is shown in Fig. 6 for the four selected sites (grey dashed line). Their average concentration is around $1 \mu \mathrm{g} \mathrm{m}^{-3}$, which is the value set at the boundaries of the domain. This value represents an important fraction of total OA, thus influences OA predictions.

$25 \%$ of the total OA over the central European sites (Cabauw and Melpitz) is attributed to the effect of the boundary conditions. During the northern wind conditions (16 to 21 May), which transfer clean air masses towards central Europe and disperse local pollution, the role of boundary conditions is maximized over Cabauw. Mace Head is the site that is influenced the most by the boundary OA concentrations $(66 \%)$, due to its proximity to the western edge of the domain. During the last days of the month, there seems to be an equal contribution of European pollution and background OA in Mace Head.

Although Finokalia is also relatively close to the borders of the domain, the calculated effect of the boundaries on OA is half than that over Mace Head (33\%). This is attributed to the high photochemical activity in southern Europe, which strengthens the role of chemical oxidation and regional SOA formation and to a much stronger predominance of westerly flow patterns in Mace Head. Nevertheless, pollution transport from major cities in Africa, especially during south winds (19 to 21 May) is not represented by the current application. This potentially contributes to an underestimation of long range transport of pollution over Finokalia.

\subsubsection{Model inter-comparison}

The OA predictions from scenario 3 (SORGAM approach) are compared against the base-case COSMO-ART simulation (VBS approach) and the observations (Fig. 6). SORGAM reproduces the daily cycle in Cabauw (orange line in Fig. 6). Nevertheless, significant deviations from the baseline scenario and measurements occur around noon and midnight hours, when SORGAM predicts unrealistically low values. During daytime, this deficit reflects the inability of SORGAM to treat the photochemical aging of SOA. Subsequently, the background aged SOA concentrations during nighttime are also low in scenario 3 predictions. Average measured OA during 3-10 May is $4 \mu \mathrm{g} \mathrm{m}^{-3}$ over Cabauw, while COSMO-ART predicts low values with SORGAM $\left(2.7 \mu \mathrm{g} \mathrm{m}^{-3}\right)$, in contrast to the more realistic results of the VBS $\left(4.1 \mu \mathrm{g} \mathrm{m}^{-3}\right)$. The OA underestimation by SORGAM is $35 \%$ but reaches around $75 \%$ during certain hours. SORGAM and VBS predictions for Mace Head and 

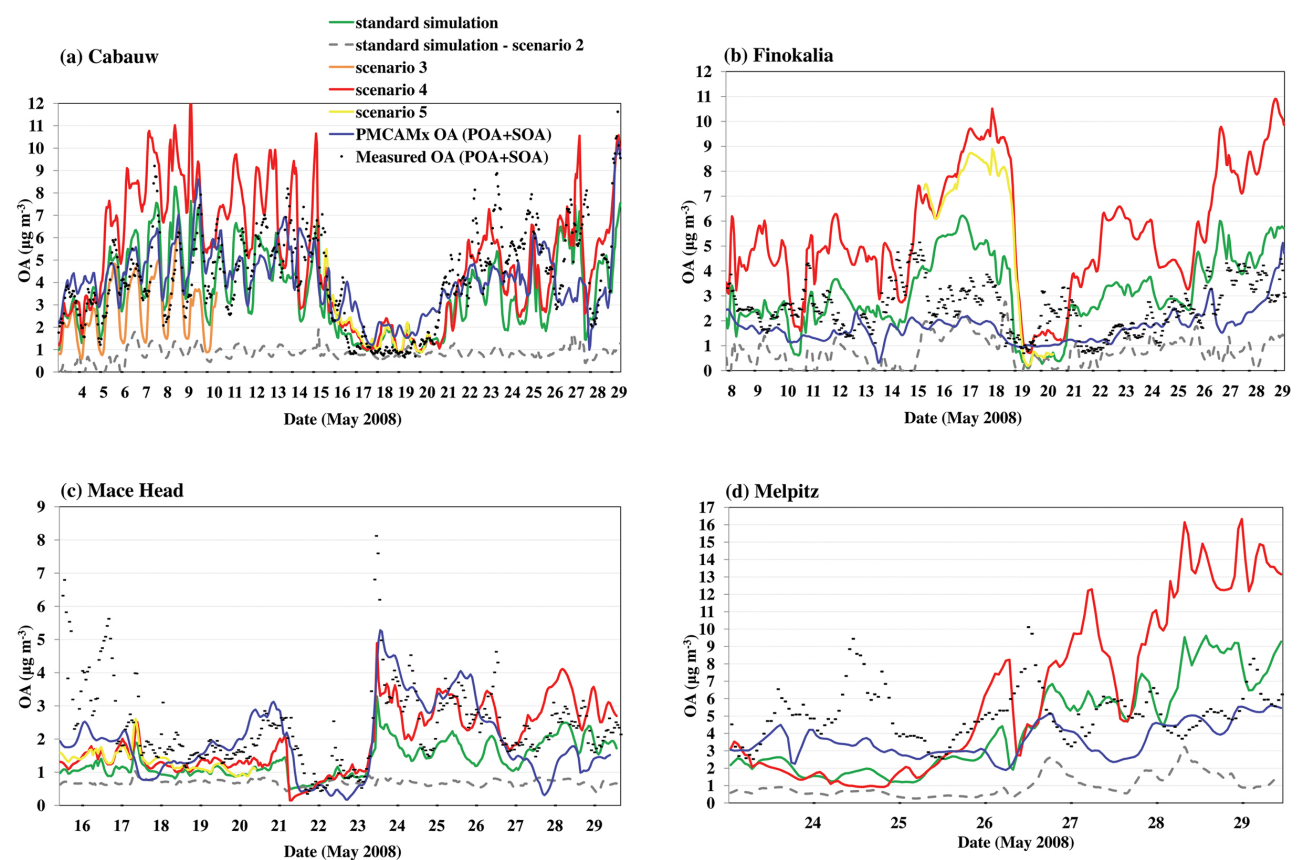

Fig. 6. COSMO-ART results for total $\mathrm{PM}_{1}$ OA hourly concentrations $\left(\mu \mathrm{g} \mathrm{m}^{-3}\right)$ from the base-case simulation and scenarios, during May 2008 over: (a) Cabauw; the legend applies for all succeeding graphs, (b) Finokalia, (c) Mace Head and (d) Melpitz. Scenarios description is

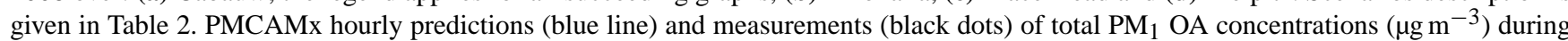
the EUCAARI campaign are also shown. Dates at the $\mathrm{x}$ axis are marked at 12:00 UTC.

Melpitz are 1.5 (scenario 3), 2.4 (base-case) and 2.2 (scenario 3), $2.8 \mu \mathrm{g} \mathrm{m}^{-3}$ (base-case), respectively. The biggest differences between the two approaches are evident in Finokalia, due to the increased photochemical activity and SOA aging, which is not simulated by scenario $3\left(0.8 \mu \mathrm{g} \mathrm{m}^{-3}\right)$ in contrast to the base-case simulation $\left(2.2 \mu \mathrm{g} \mathrm{m} \mathrm{m}^{-3}\right)$. These deviations from OA observations exist also when WRF-CHEM using the SORGAM module was applied over the eastern United States (Ahmadov et al., 2012).

The comparison of COSMO-ART to PMCAMx OA predictions (green and blue lines in Fig. 6) reveals neither large nor systematic differences. Sources of discrepancies are differences in the spatial resolution of models, emission databases applied, meteorology (online-calculated and hourly inputs from the meteorological model WRF, respectively) and differences in the chemical aging of organic matter. The latter is related to the lower aging constant rates used by COSMO-ART, and the absence of aging of the biogenic VOCs and POA in PMCAMx and COSMO-ART, respectively.

These differences cancel each other to a large extent and are most probably the reason for the non-systematic behavior of OA results. Nevertheless, common model behavior supports some aforementioned arguments (Sect. 4.2). In specific, northeastern winds towards Mace Head (16 to 17 May) and Melpitz (24 May) contribute to low PMCAMx OA predictions, similarly to COSMO-ART, and strengthen the argu- ment of poor emission representation over North Sea, Scandinavian Peninsula and at European Russia north of Moscow. In addition, the underestimation of OA levels over Finokalia during the Africa event (20 to 21 May) shows that in certain conditions African cities can be an important source of OA mass over Europe.

\subsubsection{SOA formation and constant parameters}

Figure 6 shows OA predictions by two additional simulations (scenarios 4 and 5), after modifying the aging constants as described in Sect. 3.1. OA predictions by scenario 4 (red line in Fig. 6) are in general a lot higher than observations and baseline results, because of the higher aging constant applied. The changes that correspond to the reduction of $\Delta H$ were small to moderate (5-20\% of total OA). These differences are maximized upon OA peaks (e.g high values during 5 to 15 May over Cabauw) and are minimized when OA values are low and close to background levels. The most unrealistic OA peaks predicted by this scenario occur over Finokalia and Melpitz. This is because, as aforementioned, both sites are situated within a greater area of high-OA, resulting from the increased photochemical activity and from eastern transport, respectively. Under these conditions total OA concentrations are controlled by the assumed oxidation rates of SOA.

The above shows that this configuration is not as appropriate for Europe as the base-case one. Mace Head represents an exception: the monthly average increase from this 


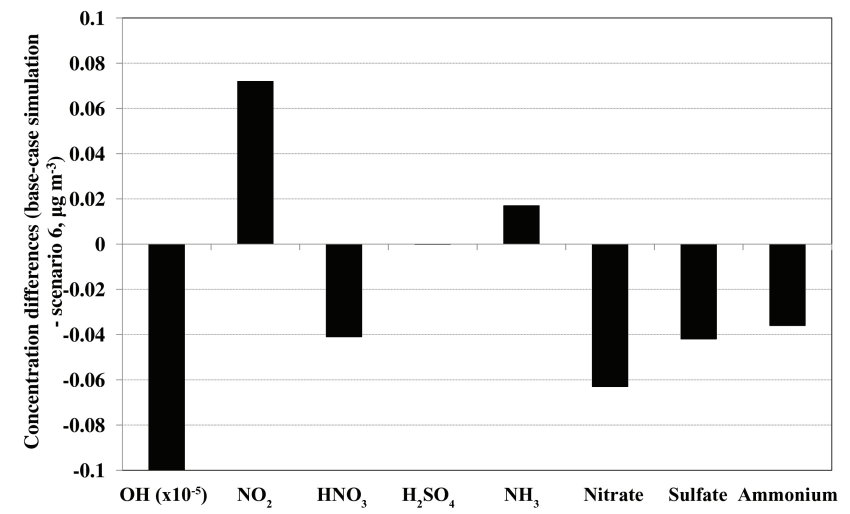

Fig. 7. Mean differences in gaseous and aerosol species ground concentrations $\left(\mathrm{OH}\right.$ in molecules $\mathrm{cm}^{-3}$, all other species in $\left.\mu \mathrm{g} \mathrm{m}^{-3}\right)$, due to SOA chemical aging over Europe during a 8-day period of May 2008. The simulations are performed by COSMO-ART and are described in Table $2 . \mathrm{H}_{2} \mathrm{SO}_{4}$ stands for sulfuric acid.

scenario is small $\left(0.5 \mu \mathrm{g} \mathrm{m}^{-3}\right)$, but results in MFE $=+38 \%$ and $\mathrm{MFB}=-30 \%$, thus to improvement of model predictions.

In order to investigate whether the unrealistic peaks stem from overestimated aerosol yields applied for VOCs, this scenario is compared to scenario 5 (yellow line in Fig. 6). As expected, SOA values are decreased in comparison to scenario 4 , but not more than $10 \%$. Thus, the dependence of aerosol yields on the $\mathrm{NO}_{\mathrm{x}}$ regime does not influence significantly OA predictions in this case. These findings strengthen the arguments for the importance of the chemical aging in comparison to the initial formation/stage of SOA in the atmosphere.

\subsubsection{SOA aging and inorganic chemistry}

The main effect of $\mathrm{OH}$ consumption during SOA oxidation is the decreased production of nitric and sulfuric acid from $\mathrm{NO}_{2}$ and $\mathrm{SO}_{2}$ oxidation, respectively. The decreased availability of acids in the atmosphere, leads to decreased levels of sulfate, nitrate and ammonium and leaves more $\mathrm{NH}_{3}$ in the gas phase. These effects are quantified by calculating the differences of the concentrations of the aforementioned species as predicted by the base-case simulation and by scenario 6 . Although values are small when averaged for an 8-day period over Europe (Fig. 7), they reach as much as $-0.5,-3$ and $-1 \mu \mathrm{g} \mathrm{m}^{-3}$ on an hourly basis for sulfate, nitrate and ammonium, respectively, in a high- $\mathrm{NO}_{\mathrm{x}}$ regime. This decrease due to SOA formation corresponds to 5-30\% of hourly SIA base-case concentrations.

SIA performance of COSMO-ART after incorporating SOA aging through the VBS scheme is encouraging. In specific, mean monthly SIA measurements and predictions over Cabauw are 5 and $5.2 \mu \mathrm{g} \mathrm{m}^{-3}$, respectively, while for Finokalia both values are $4 \mu \mathrm{g} \mathrm{m}^{-3}$. Since the number of val- ues compared here is relatively small (117 and 55, respectively), this evaluation is only indicative and not representative of the general secondary inorganic aerosol performance of COSMO-ART. Nevertheless, a detailed study towards this direction (Knote et al., 2011) showed nitrate overestimation, which is the species found here mostly decreased due to SOA aging. This indicates that the current version of COSMOART has improved performance not only in organic, but also in inorganic aerosol.

\subsubsection{Anthropogenic and biogenic SOA sources}

Figure 8 shows the average $\mathrm{PM}_{1}$ SOA concentration, biogenic fraction and average concentrations of anthropogenic and biogenic VOCs (precursor species are shown in Table 1). Over a large part of the simulation domain, biogenic SOA is the dominant OA component. This fraction reflects nonanthropogenic sources not explicitly included in the model.

Peak SOA concentrations over the latitudinal zone of continental Europe from 40 to $55^{\circ} \mathrm{N}$ (Fig. 8a) originate mainly from biogenic VOCs, although not above $60 \%$ (Fig. 8b). The chemical analysis of aircraft measurements during May 2008 (Morgan et al., 2010b) is also suggestive of the anthropogenic influence on oxygenated organic aerosol over Europe. However, that study lacks suitable information regarding gas-phase organic precursors, which is attempted here (Fig. 8c and d). COSMO-ART results show that the sum of the anthropogenic SOA precursors significantly outweighs biogenic VOCs concentrations. This is mainly reflected over the Mediterranean Sea, where the former is significantly greater than the latter. The maximum influence of anthropogenic VOCs over the Mediterranean Sea is also shown from predictions by Bergström et al. (2012) over Europe.

\section{Conclusions}

Use of the volatility basis set approach (VBS) to simulate secondary organic aerosol (SOA) formation over Europe led to improved organic aerosol predictions by the regional atmospheric model COSMO-ART and allowed investigation of their impact upon the radiative budget during May 2008.

Atmospheric circulation and air pollution transport as predicted by COSMO-ART are consistent with observations (Pikridas et al., 2010; Hildebrandt et al., 2010; Hamburger et al., 2011), which further allows for the estimation of accuracy of organic aerosol treatment and representation within the model.

The organic aerosol field has a strong regional character with high levels often far from major pollution sources reflecting their transport and chemical oxidation towards highly condensable species. This is in line with the high secondary to total organics ratio $(80$ to $95 \%)$ all over the European area for the May period. These physicochemical 
(a) $\mathrm{SOA}$

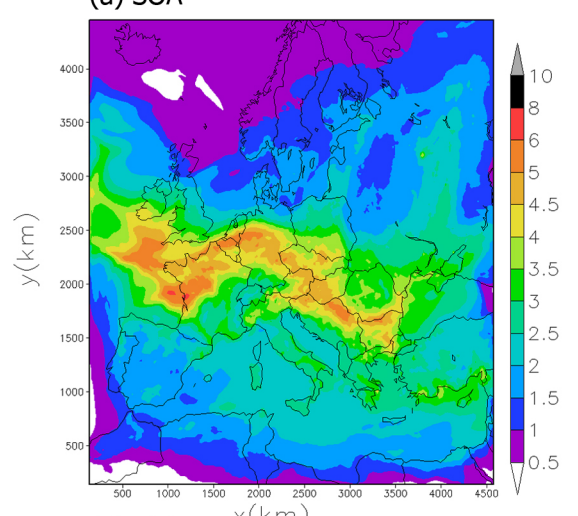

(c) aSOA prec.

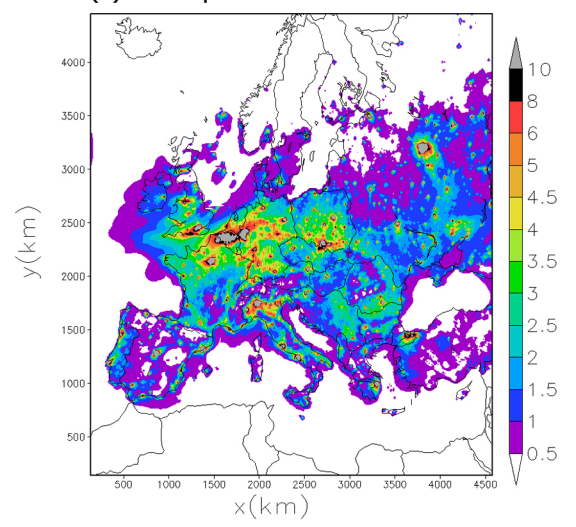

(b) bSOA fr.

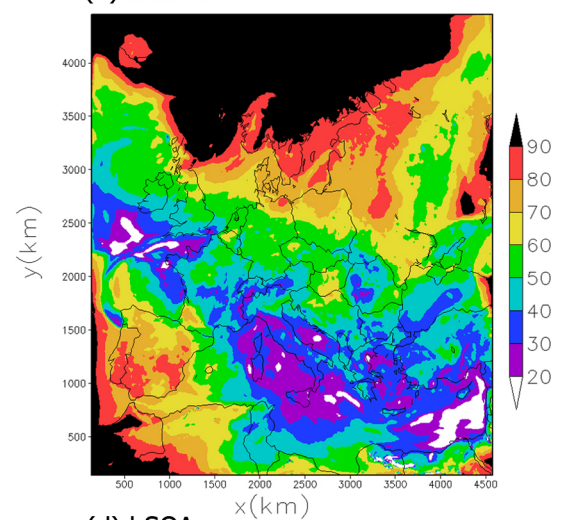

(d) bSOA prec.

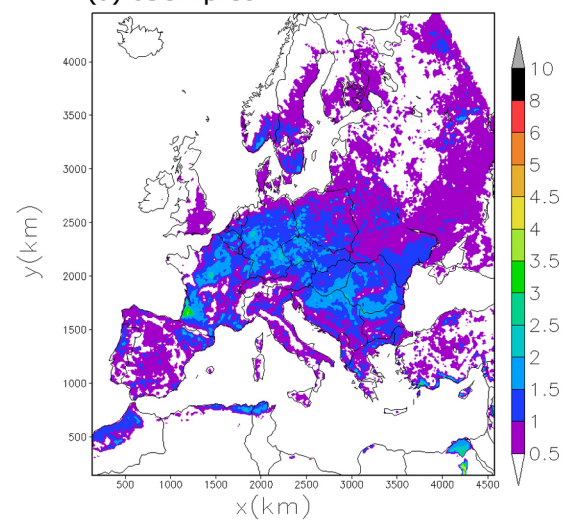

Fig. 8. Spatial distribution over Europe during a 5-day period of May 2008, of surface: (a) SOA concentrations $\left(\mu \mathrm{g} \mathrm{m}^{-3}\right)$ in $\mathrm{PM}_{1} \mathrm{mass},(\mathbf{b})$ biogenic SOA fraction (\%) (bSOA fr.), (c) anthropogenic SOA gaseous precursor (aromatics, higher alkanes, higher alkenes) (aSOA prec.) concentrations $\left(\mu \mathrm{g} \mathrm{m}^{-3}\right)$, and (d) biogenic SOA gaseous precursor (isoprene and terpenes) (bSOA prec.) concentrations $\left(\mu \mathrm{g} \mathrm{m}{ }^{-3}\right)$. All values are COSMO-ART predictions.

processes shape the monthly mean surface organic aerosol concentrations from 2.5 to $4.5 \mu \mathrm{g} \mathrm{m}^{-3}$ over most European areas. Higher SOA values are predicted to originate mainly from biogenic precursors, though anthropogenic influence is important (around $40 \%$ ), as previously suggested by aircraft measurements (Morgan et al., 2010b).

Comparison of hourly predictions with point measurements in the framework of the EUCAARI campaign shows that COSMO-ART meets the performance goals for total organic aerosol mass, as defined by Boylan and Russell (2006). This indicates that the significant reduction of surrogate species applied in the current version of VBS scheme provides COSMO-ART with both speed and accuracy.

Interactive coupling performed by COSMO-ART allows the estimation of SOA interaction with radiation on a regional scale. Results in this study show a mean monthlyaverage direct radiative forcing of around $-1.2 \mathrm{~W} \mathrm{~m}^{-2}$, imposed by SOA chemistry at the surface over Europe during May 2008, which is followed by a small decrease in temperature $(-0.1 \mathrm{~K})$. Responses are not spatially correlated with the forcing, due to the nonlinearity involved in the feedbacks among major processes. Cloud cover modifications, due to changes in particle chemical composition, water content and size distribution, result even in a positive radiative forcing, though over a limited area. This semi-direct phenomenon is also responsible for the greater global and local sensitivities to forcing (Shindell and Faluvegi, 2009). Therefore, the surface air temperature changes calculated in the current study correspond to the regional contribution of forcing imposed by SOA concentrations.

Results from the sensitivity simulations related to the secondary organic chemistry modules revealed important information related to their treatment within atmospheric models. The inability of SORGAM to treat the chemical oxidation of organic matter leads to an underestimation of $35 \%$ of average OA values against VBS predictions and measurements and up to $75 \%$ when comparing hourly values. Sensitivity tests on the parameters used within the VBS approximation showed that $\mathrm{NO}_{\mathrm{x}}$ availability causes small differences in SOA production, but the aging rate constant is very important for the predicted SOA levels.

By combining measurements with COSMO-ART predictions, the origin of organic aerosol peaks is identified. Elevated hourly organic aerosol values (4 to $10 \mu \mathrm{g} \mathrm{m}^{-3}$ ) over 
Cabauw, Mace Head and Melpitz occur when air masses are transported from the east towards these areas, while northeastern wind directions cause high values over Finokalia. Total organic aerosol concentration predictions are significantly affected by the boundary concentrations assumed in the model. $25 \%$ of total OA predictions in the central European area correspond to background concentrations.

The inter-comparison of COSMO-ART and PMCAMx against measurements can help towards identifying possible sources for model discrepancies. Organic aerosol underestimations commonly found by both models during northeastern winds over Mace Head and Melpitz are possibly caused by unidentified sources of organic precursors at the Scandinavian Peninsula and in Northern European Russia.

The effort to improve COSMO-ART organic aerosol predictions, which was addressed by Knote et al. (2011), is proven to be critical not only for organics, but also for the overall COSMO-ART aerosol performance. In specific, SOA aging is found to reduce nitrate production up to $30 \%$ on an hourly basis, while the condensation of inorganic substances upon pre-existing and SOA-rich particles, results in a monthly average increase of $5 \%$ in sulfate and ammonium formation in the accumulation mode. Thus, nitrate overestimation and sulfate underestimation found by Knote et al. (2011) are reduced after the current modifications in COSMO-ART chemistry. The consistency of secondary inorganic aerosol predictions with observations in the framework of this study is a first indication towards this conclusion.

Future research is focused on a cloud-free case of an OA episode towards the identification of a clear correlation between aerosol concentration and radiative fluxes. The indirect impact of condensing organics is included in further model development. Improvements in the SOA module will also be considered, such as a functional approach of the enthalpy of vaporization (Epstein et al., 2010), which has not yet been incorporated in organic aerosol simulations.

Acknowledgements. The authors would like to thank A. Mensah, A. Kiendler-Scharr, M. Dall'Osto, C. O'Dowd and L. Poulain concerning EUCAARI data. Final work for this publication has received funding from the project AERAS-EtS (within the framework of the Action "Supporting Postdoctoral Researchers" of the Operational Program "Education and Lifelong Learning", co-financed by the European Social Fund (ESF) and the Greek State). S. N. Pandis and C. Fountoukis were supported by the European Research Council project ATMOPACS.

The service charges for this open access publication have been covered by a Research Centre of the Helmholtz Association.

Edited by: N. Riemer

\section{References}

Ackermann, I., Hass, H., Memmesheimer, M., Ebel, A., Binkowski, F., and Shankar U.: Modal aerosol dynamics model for Europe: Development and first applications, Atmos. Environ., 32, 29812999, 1998.

Ahmadov, R., McKeen, S. A., Robinson, A. L., Bahreini, R., Middlebrook, A. M., Gouw, J. A. de, Meagher, J., Hsie, E.Y., Edgerton, E., Shaw, S., and Trainer, M.: A volatility basis set model for summertime secondary organic aerosols over the eastern United States in 2006, J. Geophys. Res., 117, D06301, doi:10.1029/2011JD016831, 2012.

Andersson-Sköld, Y. and Simpson, D.: Secondary organic aerosol formation in northern Europe: A model study, J. Geophys. Res., 106, 7357-7374, doi:10.1029/2000JD900656, 2001.

Baeumer, D., Lohmann, U., Lesins, G., Li, J., and Croft, B.: Parameterizing the optical properties of carbonaceous aerosols in the Canadian Centre for Climate Modeling and Analysis Atmospheric General Circulation Model with impacts on global radiation and energy fluxes, J. Geophys. Res., 112, D10207, doi:10.1029/2006JD007319, 2007.

Bahreini, R., Ervens, B., Middlebrook, A. M., Warneke, C., de Gouw, J. A., DeCarlo, P. F., Jimenez, J. L., Brock, C. A., Neuman, J. A., Ryerson, T. B., Stark, H., Atlas, E., Brioude, J., Fried, A., Holloway, J. S., Peischl, J., Richter, D., Walega, J., Weibring, P., Wollny, A. G., Fehsenfeld, F. C.: Organic aerosol formation in urban and industrial plumes near Houston and Dallas, Texas, J. Geophys. Res., 114, D00F16, doi:10.1029/2008JD011493, 2009.

Baldauf, M., Seifert, A., Förstner, J., Majewski, D., Raschendorfer, M., and Reinhardt, T.: Operational convective-scale numerical weather prediction with the COSMO Model: Description and sensitivities, Monthly Weather Review, 139, 3887-3905, doi:10.1175/MWR-D-10-05013.1, 2011.

Bangert, M., Kottmeier, C., Vogel, B., and Vogel, H.: Regional scale effects of the aerosol cloud interaction simulated with an online coupled comprehensive chemistry model, Atmos. Chem. Phys., 11, 4411-4423, doi:10.5194/acp-11-4411-2011, 2011.

Bangert, M., Nenes, A., Vogel, B., Vogel, H., Barahona, D., Karydis, V. A., Kumar, P., Kottmeier, C., and Blahak, U.: Saharan dust event impacts on cloud formation and radiation over Western Europe, Atmos. Chem. Phys., 12, 4045-4063, doi:10.5194/acp-124045-2012, 2012.

Bartholomé, E. and Belward, A. S.,: GLC2000: a new approach to global land cover mapping from Earth observation data, Int. J. Remote Sens., 26, 1959-1977, 2005.

Bergström, R., Denier van der Gon, H. A. C., Prévôt, A. S. H., Yttri, K. E., and Simpson, D.: Modelling of organic aerosols over Europe (2002-2007) using a volatility basis set (VBS) framework: application of different assumptions regarding the formation of secondary organic aerosol, Atmos. Chem. Phys., 12, 8499-8527, doi:10.5194/acp-12-8499-2012, 2012.

Bessagnet, B., Menut, L., Curci, G., Hodzic, A., Guillaume, B., Liousse, C., Moukhtar, S., Pun, B., Seigneur, C., and Schulz, M.: Regional modeling of carbonaceous aerosols over Europe - focus on secondary organic aerosols, Journal of Atmospheric Chemistry, 61, 175-202, doi:10.1007/s10874-009-9129-2, 2008.

Bohren, C. F. and Huffman, D. R.: Absorption and Scattering of Light by Small Particles, Wiley, New York, USA, 1983.

Boylan, J. and Russell, A.: PM and light extinction model performance metrics, goals, and criteria for three-dimensional 
air quality models, Atmos. Environ., 40(26), 4946-4959, doi:10.1016/j.atmosenv.2005.09.087, 2006.

Carslaw, K. S., Boucher, O., Spracklen, D. V., Mann, G. W., Rae, J. G. L., Woodward, S., and Kulmala, M.: A review of natural aerosol interactions and feedbacks within the Earth system, Atmos. Chem. Phys., 10, 1701-1737, doi:10.5194/acp-10-17012010, 2010.

Chen, Q., Farmer, D. K., Schneider, J., Zorn, S. R., Heald, C. L., Karl, T. G., Guenther, A., Allan, J. D., Robinson, N., Coe, H., Kimmel, J. R., Pauliquevis, T., Borrmann, S., Pöschl, U., Andreae, M. O., Artaxo, P., Jimenez, J. L., and Martin, S. T.: Mass spectral characterization of submicron biogenic organic particles in the Amazon Basin, Geophys. Res. Lett., 36, 5 pp., doi:200910.1029/2009GL039880, 2009.

Chuang, M.-T., Zhang, Y., and Kang, D.: Application of WRF/Chem-MADRID for real-time air quality forecasting over the Southeastern United States, Atmos. Environ., 45, 6241-6250, doi:10.1016/j.atmosenv.2011.06.071, 2011.

de Gouw, J. A., Middlebrook, A. M., Warneke, C., Goldan, P. D., Kuster, W. C., Roberts, J. M., Fehsenfeld, F. C., Worsnop, D. R., Canagaratna, M. R., Pszenny, A. A. P., Keene, W. C., Marchewka, M., Bertman, S. B., and Bates, T. S.: Budget of organic carbon in a polluted atmosphere: Results from the New England Air Quality Study in 2002, J. Geophys. Res., 110, 22 pp., doi:10.1029/2004JD005623, 2005.

de Gouw, J. A., Welsh-Bon, D., Warneke, C., Kuster, W. C., Alexander, L., Baker, A. K., Beyersdorf, A. J., Blake, D. R., Canagaratna, M., Celada, A. T., Huey, L. G., Junkermann, W., Onasch, T. B., Salcido, A., Sjostedt, S. J., Sullivan, A. P., Tanner, D. J., Vargas, O., Weber, R. J., Worsnop, D. R., Yu, X. Y., and Zaveri, R.: Emission and chemistry of organic carbon in the gas and aerosol phase at a sub-urban site near Mexico City in March 2006 during the MILAGRO study, Atmos. Chem. Phys., 9, 34253442, doi:10.5194/acp-9-3425-2009, 2009.

Denier van der Gon, H., Visschedijk, A., van der Brugh, H., and Droge, R.: A high resolution European emission data base for the year 2005, A contribution to UBA- Projekt PAREST: Particle Reduction Strategies, TNO-report TNO-034-UT-2010-01895 RPTML, 2010.

Donahue, N. M., Robinson, A. L., Stanier, C. O., and Pandis, S. N.: Coupled partitioning, dilution, and chemical aging of semivolatile organics, Environ. Sci. Technol., 40, 2635-2643, 2006

Donahue, N. M., Epstein, S. A., Pandis, S. N., and Robinson, A. L.: A two-dimensional volatility basis set: 1. organic-aerosol mixing thermodynamics, Atmos. Chem. Phys., 11, 3303-3318, doi:10.5194/acp-11-3303-2011, 2011

Donahue, N. M., Kroll, J. H., Pandis, S. N., and Robinson, A. L.: A two-dimensional volatility basis set - Part 2: Diagnostics of organic-aerosol evolution, Atmos. Chem. Phys., 12, 615-634, doi:10.5194/acp-12-615-2012, 2012.

Dzepina, K., Volkamer, R. M., Madronich, S., Tulet, P., Ulbrich, I. M., Zhang, Q., Cappa, C. D., Ziemann, P. J., and Jimenez, J. L.: Evaluation of recently-proposed secondary organic aerosol models for a case study in Mexico City, Atmos. Chem. Phys., 9, 5681-5709, doi:10.5194/acp-9-5681-2009, 2009.

Elleman, R. A. and Covert, D. S.: Aerosol size distribution modeling with the Community Multiscale Air Quality modeling system in the Pacific Northwest: 1. Model comparison to observations,
J. Geophys. Res., 114, 16 pp., doi:200910.1029/2008JD010791, 2009.

Emmons, L. K., Walters, S., Hess, P. G., Lamarque, J.-F., Pfister, G. G., Fillmore, D., Granier, C., Guenther, A., Kinnison, D., Laepple, T., Orlando, J., Tie, X., Tyndall, G., Wiedinmyer, C., Baughcum, S. L., and Kloster, S.: Description and evaluation of the Model for Ozone and Related chemical Tracers, version 4 (MOZART-4), Geosci. Model Dev., 3, 43-67, doi:10.5194/gmd3-43-2010, 2010.

Farina, S. C., Adams, P. J., and Pandis, S. N.: Modeling global secondary organic aerosol formation and processing with the volatility basis set: Implications for anthropogenic secondary organic aerosol, J. Geophys. Res., 115, D09202, doi:10.1029/2009JD013046, 2010.

Forster, P., V. Ramaswamy, P. Artaxo, T. Berntsen, R. Betts, D.W. Fahey, J. Haywood, J. Lean, D.C. Lowe, G. Myhre, J. Nganga, R. Prinn, G. Raga, M. Schulz and R. Van Dorland: Changes in Atmospheric Constituents and in Radiative Forcing. In: Climate Change 2007: The Physical Science Basis. Contribution of Working Group I to the Fourth Assessment Report of the Intergovernmental Panel on Climate Change, edited by: Solomon, S., Qin, D., Manning, M., Chen, Z., Marquis, M., Averyt, K. B., Tignor, M., and Miller, H. L., Cambridge University Press, Cambridge, United Kingdom and New York, NY, USA, 131-234, 2007.

Fountoukis, C. and Nenes, A.: ISORROPIA II: A computationally efficient thermodynamic equilibrium model for $\mathrm{K}^{+}$ $\mathrm{Ca}^{2+}-\mathrm{Mg}^{2+}-\mathrm{NH}_{4}^{+}-\mathrm{Na}^{+}-\mathrm{SO}_{4}^{2-}-\mathrm{NO}_{3}^{-}-\mathrm{Cl}^{-}-\mathrm{H}_{2} \mathrm{O}$ aerosols, Atmos. Chem. Phys., 7(17), 4639-4659, doi:10.5194/acp-7-46392007, 2007.

Fountoukis, C., Racherla, P. N., Denier van der Gon, H. A. C., Polymeneas, P., Charalampidis, P. E., Pilinis, C., Wiedensohler, A., Dall'Osto, M., O'Dowd, C., and Pandis, S. N.: Evaluation of a three-dimensional chemical transport model (PMCAMx) in the European domain during the EUCAARI May 2008 campaign, Atmos. Chem. Phys., 11, 10331-10347, doi:10.5194/acp11-10331-2011, 2011.

Geiger, H., Barnes, I., Bejan, I., Benter, T., and Spittler, M.: The tropospheric degradation of isoprene: an updated module for the regional atmospheric chemistry mechanism, Atmos. Environ., 37, 1503-1519, 2003.

Grell, G. A., Peckham, S. E., Schmitz, R., McKeen, S. A., Frost, G., Skamarock, W. C. and Eder, B.: Fully coupled "online" chemistry within the WRF model, Atmos. Environ., 39(37), 69576975, doi:10.1016/j.atmosenv.2005.04.027, 2005.

Hamburger, T., McMeeking, G., Minikin, A., Birmili, W., Dall'Osto, M., O’Dowd, C., Flentje, H., Henzing, B., Junninen, H., Kristensson, A., de Leeuw, G., Stohl, A., Burkhart, J. F., Coe, H., Krejci, R., and Petzold, A.: Overview of the synoptic and pollution situation over Europe during the EUCAARILONGREX field campaign, Atmos. Chem. Phys., 11, 10651082, doi:10.5194/acp-11-1065-2011, 2011.

Han, Z., Li, J., Xia, X. and Zhang, R.: Investigation of direct radiative effects of aerosols in dust storm season over East Asia with an online coupled regional climatechemistry-aerosol model, Atmos. Environ., 54, 688-699, doi:10.1016/j.atmosenv.2012.01.041, 2012.

Herwehe, J. A., Otte, T. L., Mathur, R., and Rao, S. T.: Diagnostic analysis of ozone concentrations simulated by two 
regional-scale air quality models, Atmos. Environ., 45, 59575969, doi:10.1016/j.atmosenv.2011.08.011, 2011.

Hildebrandt, L., Engelhart, G. J., Mohr, C., Kostenidou, E., Lanz, V. A., Bougiatioti, A., DeCarlo, P. F., Prevot, A. S. H., Baltensperger, U., Mihalopoulos, N., Donahue, N. M., and Pandis, S. N.: Aged organic aerosol in the Eastern Mediterranean: the Finokalia Aerosol Measurement Experiment - 2008, Atmos. Chem. Phys., 10, 4167-4186, doi:10.5194/acp-10-4167-2010, 2010.

Hodzic, A., Jimenez, J. L., Madronich, S., Canagaratna, M. R., DeCarlo, P. F., Kleinman, L., and Fast, J.: Modeling organic aerosols in a megacity: potential contribution of semi-volatile and intermediate volatility primary organic compounds to secondary organic aerosol formation, Atmos. Chem. Phys., 10, 5491-5514, doi:10.5194/acp-10-5491-2010, 2010.

Jimenez, J. L., Canagaratna, M. R., Donahue, N. M., Prévôt, A. S., Zhang, Q., Kroll, J. H., DeCarlo, P. F., Allan, J. D., Coe, H., Ng, N. L., Aiken, A. C., Docherty, K. S., Ulbrich, I. M., Grieshop, A. P., Robinson, A. L., Duplissy, J., Smith, J. D., Wilson, K. R., Lanz, V. A., Hueglin, C., Sun, Y. L., Tian, J., Laaksonen, A., Raatikainen, T., Rautiainen, J., Vaattovaara, P., Ehn, M., Kulmala, M., Tomlinson, J. M., Collins, D. R., Cubison, M. J., Dunlea, E. J., Huffman, J. A., Onasch, T. B., Alfarra, M. R., Williams, P. I., Bower, K., Kondo, Y., Schneider, J., Drewnick, F., Borrmann, S., Weimer, S, Demerjian, K., Salcedo, D., Cottrell, L., Griffin, R., Takami, A., Miyoshi, T., Hatakeyama, S., Shimono, A., Sun, J. Y., Zhang, Y. M., Dzepina, K., Kimmel, J. R., Sueper, D, Jayne, J. T., Herndon, S. C., Trimborn, A. M., Williams, L. R., Wood, E. C., Middlebrook, A. M., Kolb, C. E., Baltensperger, U., and Worsnop, D. R.: Evolution of organic aerosols in the atmosphere, Science. 326, 1525-1529, doi:10.1126/science.1180353, 2009.

Johnson, B. T., Shine, K. P., and Forster, P. M.: The semi-direct aerosol effect: The impact of absorbing aerosols on marine stratocumulus, Q. J. Roy. Meteorol. Soc., 130, 1407-1422, 2004.

Kanakidou, M., Seinfeld, J. H., Pandis, S. N., Barnes, I., Dentener, F. J., Facchini, M. C., Van Dingenen, R., Ervens, B., Nenes, A., Nielsen, C. J., Swietlicki, E., Putaud, J. P., Balkanski, Y., Fuzzi, S., Horth, J., Moortgat, G. K., Winterhalter, R., Myhre, C. E. L., Tsigaridis, K., Vignati, E., Stephanou, E. G., and Wilson, J.: Organic aerosol and global climate modelling: a review, Atmos. Chem. Phys., 5, 1053-1123, doi:10.5194/acp-5-1053-2005, 2005.

Karl, M., Tsigaridis, K., Vignati, E., and Dentener, F.: Formation of secondary organic aerosol from isoprene oxidation over Europe, Atmos. Chem. Phys., 9, 7003-7030, doi:10.5194/acp-97003-2009, 2009.

Karydis, V. A., Tsimpidi, A. P., Fountoukis, C., Nenes, A., Zavala, M., Lei, W. F., Molina, L. T., and Pandis, S. N.: Simulating the fine and coarse inorganic particulate matter concentrations in a polluted megacity, Atmos. Environ., 44, 608-620, doi:10.1016/j.atmosenv.2009.11.023,25 2010.

Knote,C., Brunner,D., Vogel,H., Allan,J., Asmi,A., Äijälä,M., Carbone,S., vanderGon, H. D., Jimenez, J. L., Kiendler-Scharr, A., Mohr, C., Poulain, L., Prévôt, A. S. H., Swietlicki, E., and Vogel, B.: Towards an online-coupled chemistry-climate model: evaluation of trace gases and aerosols in COSMO-ART, Geosci. Model Dev., 4, 1077-1102, doi:10.5194/gmd-4-1077-2011, 2011.
Kuenen, J., Denier van der Gon, H., Visschedijk, A., van der Brugh, H., and Gijlswijk R.: MACC European emission inventory for the years 2003-2007, TNO-report TNO-060-UT-2011-00588, TNO: Netherlands Organisation for Applied Scientific Research TNO, Utrecht, The Netherlands, 2011.

Kulmala, M., Asmi, A., Lappalainen, H. K., Baltensperger, U., Brenguier, J.-L., Facchini, M. C., Hansson, H.-C., Hov, Ø., O'Dowd, C. D., Pöschl, U., Wiedensohler, A., Boers, R., Boucher, O., de Leeuw, G., Denier van der Gon, H. A. C., Feichter, J., Krejci, R., Laj, P., Lihavainen, H., Lohmann, U., McFiggans, G., Mentel, T., Pilinis, C., Riipinen, I., Schulz, M., Stohl, A., Swietlicki, E., Vignati, E., Alves, C., Amann, M., Ammann, M., Arabas, S., Artaxo, P., Baars, H., Beddows, D. C. S., Bergström, R., Beukes, J. P., Bilde, M., Burkhart, J. F., Canonaco, F., Clegg, S. L., Coe, H., Crumeyrolle, S., D’Anna, B., Decesari, S., Gilardoni, S., Fischer, M., Fjaeraa, A. M., Fountoukis, C., George, C., Gomes, L., Halloran, P., Hamburger, T., Harrison, R. M., Herrmann, H., Hoffmann, T., Hoose, C., Hu, M., Hyvärinen, A., Hõrrak, U., Iinuma, Y., Iversen, T., Josipovic, M., Kanakidou, M., Kiendler-Scharr, A., Kirkevåg, A., Kiss, G., Klimont, Z., Kolmonen, P., Komppula, M., Kristjánsson, J.-E., Laakso, L., Laaksonen, A., Labonnote, L., Lanz, V. A., Lehtinen, K. E. J., Rizzo, L. V., Makkonen, R., Manninen, H. E., McMeeking, G., Merikanto, J., Minikin, A., Mirme, S., Morgan, W. T., Nemitz, E., O’Donnell, D., Panwar, T. S., Pawlowska, H., Petzold, A., Pienaar, J. J., Pio, C., Plass-Duelmer, C., Prévôt, A. S. H., Pryor, S., Reddington, C. L., Roberts, G., Rosenfeld, D., Schwarz, J., Seland, Ø., Sellegri, K., Shen, X. J., Shiraiwa, M., Siebert, H., Sierau, B., Simpson, D., Sun, J. Y., Topping, D., Tunved, P., Vaattovaara, P., Vakkari, V., Veefkind, J. P., Visschedijk, A., Vuollekoski, H., Vuolo, R., Wehner, B., Wildt, J., Woodward, S., Worsnop, D. R., van Zadelhoff, G.-J., Zardini, A. A., Zhang, K., van Zyl, P. G., Kerminen, V.-M., Carslaw, K. S., and Pandis, S. N.: General overview: European Integrated project on Aerosol Cloud Climate and Air Quality interactions (EUCAARI) - integrating aerosol research from nano to global scales, Atmos. Chem. Phys., 11, 13061-13143, doi:10.5194/acp11-13061-2011, 2011.

Lane, T. E., Donahue, N. M., and Pandis, S. N.: Simulating secondary organic aerosol formation using the volatility basis-set approach in a chemical transport model, Atmos. Environ., 42, 7439-7451, doi:10.1016/j.atmosenv.2008.06.026, 2008.

Liao, H., Henze, D. K., Seinfeld, J. H., Wu, S. L., and Mickley, L. J.: Biogenic secondary organic aerosol over the United States: Comparison of climatological simulations with observations, J. Geophys. Res.-Atmos., 112, D06201, doi:10/1029/2006JD007813, 2007.

Majewski, D., Liermann, D., Prohl, P., Ritter, B., Buchhold, M., Hanisch, T., Paul, G., Wergen, W. and Baumgardner, J.: The Operational Global Icosahedral-Hexagonal Gridpoint Model GME: Description and High-Resolution Tests, Monthly Weather Review, 130(2), 319-338, doi:10.1175/15200493(2002)130;0319:TOGIHG;2.0.CO;2, 2002.

Ming, Y., Ramaswamy, V., Ginoux, P. A. and Horowitz, L. H.: Direct radiative forcing of anthropogenic organic aerosol, J. Geophys. Res., 110, 12, doi:200510.1029/ 2004JD005573, 2005.

Morgan, W. T., Allan, J. D., Bower, K. N., Esselborn, M., Harris, B., Henzing, J. S., Highwood, E. J., Kiendler-Scharr, A., McMeeking, G. R., Mensah, A. A., Northway, M. J., Osborne, 
S., Williams, P. I., Krejci, R., and Coe, H.: Enhancement of the aerosol direct radiative effect by semi-volatile aerosol components: airborne measurements in North-Western Europe, Atmos. Chem. Phys., 10, 8151-8171, doi:10.5194/acp-10-81512010, 2010a.

Morgan, W. T., Allan, J. D., Bower, K. N., Highwood, E. J., Liu, D., McMeeking, G. R., Northway, M. J., Williams, P. I., Krejci, R. and Coe, H.: Airborne measurements of the spatial distribution of aerosol chemical composition across Europe and evolution of the organic fraction, Atmos. Chem. Phys., 10, 4065-4083, doi:10.5194/acp-10-4065-2010, 2010 b.

Murphy, B. N. and Pandis, S. N.: Simulating the formation of semivolatile primary and secondary organic aerosol in a regional chemical transport model, Environ. Sci. Technol., 43, 47224728, 2009.

Murphy, B. N. and Pandis, S. N.: Exploring summertime organic aerosol formation in the eastern United States using a regionalscale budget approach and ambient measurements, J. Geophys.Res., 115, D24216, doi:10.1029/2010JD014418, 2010.

Murphy, B. N., Donahue, N. M., Fountoukis, C., and Pandis, S. N.: Simulating the oxygen content of ambient organic aerosol with the $2 \mathrm{D}$ volatility basis set, Atmospheric Chemistry and Physics, 11, 7859-7873, doi:10.5194/acp-11-7859-2011, 2011.

Murphy, B. N., Donahue, N. M., Fountoukis, C., Dall'Osto, M., O'Dowd, C., Kiendler-Scharr, A., and Pandis, S. N.: Functionalization and fragmentation during ambient organic aerosol aging: application of the 2-D volatility basis set to field studies, Atmos. Chem. Phys., 12, 10797-10816, doi:10.5194/acp-1210797-2012, 2012.

Myhre, G., Berglen, T. F., Johnsrud, M., Hoyle, C. R., Berntsen, T. K., Christopher, S. A., Fahey, D. W., Isaksen, I. S. A., Jones, T. A., Kahn, R. A., Loeb, N., et al.: Modelled radiative forcing of the direct aerosol effect with multi-observation evaluation, Atmos. Chem. Phys., 9, 1365-1392, doi:10.5194/acp-9-1365-2009, 2009.

O’Donnell, D., Tsigaridis, K., and Feichter, J.: Estimating the direct and indirect effects of secondary organic aerosols using ECHAM5-HAM, Atmos. Chem. Phys., 11, 8635-8659, doi:10.5194/acp-11-8635-2011, 2011.

Penner, J. E., Zhang, S. Y., and Chuang, C. C.: Soot and smoke aerosol may not warm climate, J. Geophys. Res., 108, 4657, doi:10.1029/2003JD003409, 2003.

Pierce, J. R., Leaitch, W. R., Liggio, J., Westervelt, D. M., Wainwright, C. D., Abbatt, J. P. D., Ahlm, L., Al-Basheer, W., Cziczo, D. J., Hayden, K. L., Lee, A. K. Y., Li, S.-M., Russell, L. M., Sjostedt, S. J., Strawbridge, K. B., Travis, M., Vlasenko, A., Wentzell, J. J. B., Wiebe, H. A., Wong, J. P. S., and Macdonald, A. M.: Nucleation and condensational growth to CCN sizes during a sustained pristine biogenic SOA event in a forested mountain valley, Atmos. Chem. Phys., 12, 3147-3163, doi:10.5194/acp-12-3147-2012, 2012.

Pikridas, M., Bougiatioti, A., Hildebrandt, L., Engelhart, G. J., Kostenidou, E., Mohr, C., Prévôt, A. S. H., Kouvarakis, G., Zarmpas, P., Burkhart, J. F., Lee, B.-H., Psichoudaki, M., Mihalopoulos, N., Pilinis, C., Stohl, A., Baltensperger, U., Kulmala, M., and Pandis, S. N.: The Finokalia Aerosol Measurement Experiment - 2008 (FAME-08): an overview, Atmos. Chem. Phys., 10, 6793-6806, doi:10.5194/acp-10-6793-2010, 2010.
Riemer, N., Vogel, H., Vogel, B., and Fiedler, F.: Modeling aerosols on the mesoscale- $\gamma$ : Treatment of soot aerosol and its radiative effects, J. Geophys. Res., 108, 16 pp., doi:10.1029/2003JD003448, 2003.

Ritter, B. and Geleyn, J.-F.: A comprehensive scheme for numerical weather prediction models with potential applications in climate simulations, Mon. Weather Rev., 120, 303-325, 1992.

Robinson, A. L., Donahue, N. M., Shrivastava, M. K., Weitkamp, E. A., Sage, A. M., Grieshop, A. P., Lane, T. E., Pierce, J. R., and Pandis, S. N.: Rethinking organic aerosols: Semivolatile emissions and photochemical aging, Science, 315, 1259-1262, doi:10.1126/science.1133061, 2007.

Robinson, N. H., Hamilton, J. F., Allan, J. D., Langford, B., Oram, D. E., Chen, Q., Docherty, K., Farmer, D. K., Jimenez, J. L., Ward, M. W., Hewitt, C. N., Barley, M. H., Jenkin, M. E., Rickard, A. R., Martin, S. T., McFiggans, G., and Coe, H.: Evidence for a significant proportion of secondary organic aerosol from isoprene above a maritime tropical forest, Atmos. Chem. Phys., 11, 1039-1050, doi:10.5194/acp-11-1039-2011, 2011.

Schell, B., Ackermann, I. J., Binkowski, F. S., and Ebel, A.: Modeling the formation of secondary organic aerosol within a comprehensive air quality model system, J. Geophys. Res., 106, 2827528293, 2001.

Schnaiter, M., Linke, C., Möhler, O., Naumann, K.-H., Saathoff, H., Wagner, R., Schurath, U., and Wehner, B.: Absorption amplification of black carbon internally mixed with secondary organic aerosol, J. Geophys. Res., 110, 11 pp., doi:200510.1029/2005JD006046, 2005.

Shindell, D. and Faluvegi, G.: Climate response to regional radiative forcing during the twentieth century, Nature Geosci., 2, 294-300, doi:10.1038/ngeo473, 2009.

Shrivastava, M. K., Lane, T. E., Donahue, N. M., Pandis, S. N., and Robinson, A. L.: Effects of gas particle partitioning and aging of primary emissions on urban and regional organic aerosol concentrations, J. Geophys. Res., 113, 16 pp., doi:200810.1029/2007JD009735, 2008.

Shrivastava, M., Fast, J., Easter, R., Gustafson Jr., W. I., Zaveri, R. A., Jimenez, J. L., Saide, P., and Hodzic, A.: Modeling organic aerosols in a megacity: comparison of simple and complex representations of the volatility basis set approach, Atmos. Chem. Phys., 11, 6639-6662, doi:10.5194/acp-11-6639-2011, 2011.

Simpson, D., Yttri, K. E., Klimont, Z., Kupiainen, K., Caseiro, A., Gelencsér, A., Pio, C., Puxbaum, H., and Legrand, M.: Modeling carbonaceous aerosol over Europe: Analysis of the CARBOSOL and EMEP EC/OC campaigns, J. Geophys. Res., 112, doi:10.1029/2006JD008158, 2007.

Spindler, G., Brüggemann, E., Gnauk, T., Grüner, A., Müller, K., and Herrmann, H.: A four-year size-segregated characterization study of particles $\mathrm{PM}_{10}, \mathrm{PM}_{2.5}$ and $\mathrm{PM}_{1}$ depending on air mass origin at Melpitz, Atmos. Environ., 44, 164-173, doi:10.1016/j.atmosenv.2009.10.015, 2010.

Stanelle, T., Vogel, B., Vogel, H., Bäumer, D., and Kottmeier, C.: Feedback between dust particles and atmospheric processes over West Africa during dust episodes in March 2006 and June 2007, Atmos. Chem. Phys., 10, 10771-10788, doi:10.5194/acp10-10771-2010, 2010.

Stern, R., Builtjes, P., Schaap, M., Timmermans, R., Vautard, R., Hodzic, A., Memmesheimer, M., Feldmann, H., Renner, E., Wolke, R., and Kerschbaumer, A.: A model 
inter-comparison study focussing on episodes with elevated $\mathrm{PM}_{10}$ concentrations, Atmos. Environ., 42, 4567-4588, doi:10.1016/j.atmosenv.2008.01.068, 2008.

Stockwell, W. R., Middleton, P., and Chang, J. S.: The second generation regional acid deposition model chemical mechanism for regional air quality modelling, J. Geophys. Res., 95, 16343-16367, 1990.

Tsigaridis, K., Lathière, J., Kanakidou, M., and Hauglustaine, D. A.: Naturally driven variability in the global secondary organic aerosol over a decade, Atmos. Chem. Phys., 5, 1891-1904, doi:10.5194/acp-5-1891-2005, 2005.

Tsimpidi, A. P., Karydis, V. A., Zavala, M., Lei, W., Molina, L., Ulbrich, I. M., Jimenez, J. L., and Pandis, S. N.: Evaluation of the volatility basis-set approach for the simulation of organic aerosol formation in the Mexico City metropolitan area, Atmos. Chem. Phys., 10, 525-546, doi:10.5194/acp-10-525-2010, 2010.

Tsimpidi, A. P., Karydis, V. A., Zavala, M., Lei, W., Bei, N., Molina, L., and Pandis, S. N.: Sources and production of organic aerosol in Mexico City: insights from the combination of a chemical transport model (PMCAMx-2008) and measurements during MILAGRO, Atmos. Chem. Phys., 11, 5153-5168, doi:10.5194/acp11-5153-2011, 2011.

Vogel, B., Fiedler, F., and Vogel, H.: Influence of topography and biogenic volatile organic compounds emission in the state of Baden-Wurttemberg on ozone concentrations during episodes of high air temperatures, J. Geophys. Res., 100, 22907-22928, 1995.

Vogel, B., Hoose, C., Vogel, H., and Kottmeier, C.: A model of dust transport applied to the Dead Sea Area, Meteorol. Zeitschr., 15, 611-624, doi:10.1127/0941-2948/2006/0168, 2006.
Vogel, B., Vogel, H., Bäumer, D., Bangert, M., Lundgren, K., Rinke, R., and Stanelle, T.: The comprehensive model system COSMOART - Radiative impact of aerosol on the state of the atmosphere on the regional scale, Atmos. Chem. Phys., 9, 8661-8680, doi:10.5194/acp-9-8661-2009, 2009.

Volkamer, R., Jimenez, J. L., Martini, F. S., Dzepina, K., Zhang, Q., Salcedo, D., Molina, L. T., Worsnop, D. R., and Molina, M. J.: Secondary organic aerosol formation from anthropogenic air pollution: Rapid and higher than expected, Geophys. Res. Lett., 33, 4 pp., doi:200610.1029/2006GL026899, 2006.

Zanis, P., Ntogras, C., Zakey, A., Pytharoulis, I., and Karacostas, T.: Regional climate feedback of anthropogenic aerosols over Europe using RegCM3, Clim Res, 52, 267-278, doi:10.3354/cr01070, 2012.

Zhang, Q., Jimenez, J. L., Canagaratna, M. R., Allan, J. D., Coe, H., Ulbrich, I., Alfarra, M. R., Takami, A., Middlebrook, A M., Sun, Y. L., Dzepina, K., Dunlea, E., Docherty, K., DeCarlo, P. F., Salcedo, D., Onasch, T., Jayne, J. T., Miyoshi, T., Shimono, A., Hatakeyama, S., Takegawa, N., Kondo, Y., Schneider, J., Drewnick, F., Borrmann, S., Weimer, S., Demerjian, K., Williams, P., Bower, K., Bahreini, R., Cottrell, L., Griffin, R. J., Rautiainen, J., Sun, J. Y., Zhang, Y. M., and Worsnop, D. R.: Ubiquity and dominance of oxygenated species in organic aerosols in anthropogenically-influenced Northern Hemisphere midlatitudes, Geophys. Res. Lett., 34, 15 L13801, doi:10.1029/2007GL029979, 2007.

Zhao, C., Liu, X., and Leung, L. R.: Impact of the Desert dust on the summer monsoon system over Southwestern North America, Atmos. Chem. Phys., 12, 3717-3731, doi:10.5194/acp-12-37172012, 2012. 